IZA DP No. 4753

Returns to Education and Macroeconomic Shocks: Evidence from Argentina

Florencia López Bóo

February 2010 


\title{
Returns to Education and Macroeconomic Shocks: Evidence from Argentina
}

\author{
Florencia López Bóo \\ Inter-American Development Bank, \\ University of Oxford and IZA
}

\section{Discussion Paper No. 4753 \\ February 2010}

\author{
IZA \\ P.O. Box 7240 \\ 53072 Bonn \\ Germany \\ Phone: +49-228-3894-0 \\ Fax: +49-228-3894-180 \\ E-mail: iza@iza.org
}

\begin{abstract}
Any opinions expressed here are those of the author(s) and not those of IZA. Research published in this series may include views on policy, but the institute itself takes no institutional policy positions.

The Institute for the Study of Labor (IZA) in Bonn is a local and virtual international research center and a place of communication between science, politics and business. IZA is an independent nonprofit organization supported by Deutsche Post Foundation. The center is associated with the University of Bonn and offers a stimulating research environment through its international network, workshops and conferences, data service, project support, research visits and doctoral program. IZA engages in (i) original and internationally competitive research in all fields of labor economics, (ii) development of policy concepts, and (iii) dissemination of research results and concepts to the interested public.
\end{abstract}

IZA Discussion Papers often represent preliminary work and are circulated to encourage discussion. Citation of such a paper should account for its provisional character. A revised version may be available directly from the author. 
IZA Discussion Paper No. 4753

February 2010

\section{ABSTRACT}

\section{Returns to Education and Macroeconomic Shocks: Evidence from Argentina}

Returns to schooling in urban Argentina increased from 1992 to 2003, a period of economic reforms and macroeconomic volatility. In this paper I provide the most consistent estimates of returns to education so far, while I also investigate earnings profiles over time. This paper contributes to the existing literature by employing a variety of methodologies in order to estimate these returns and by using macroeconomic time series to explore shifts in earnings. The pattern of the increasing returns to education changes after the 2001 crisis. Until then, increasing convexity in the earnings-education profile reflects increasing or stable earnings for college graduates combined with decreasing earnings for the less educated. After the crisis, the increasing premium to education results from wages falling at a faster pace for the less educated than for college graduates. This result is robust to endogenous supply responses, selection, specification, changes in the functional form and to the inclusion of household fixed effects. I also find that rates of return to education are upward biased by up to 20 per cent by the omission of unobserved family background factors (i.e. family fixed effects). Surprisingly, after controlling for macroeconomic variables I still find a statistically and economically significant downward trend for all earnings, particularly those of primary completers.

JEL Classification: $\quad \mathrm{I} 21, \mathrm{~J} 31$

Keywords: returns to schooling, earnings profiles, occupations, macroeconomic shocks, policy swings, Argentina

Corresponding author:

Florencia López Bóo

Inter-American Development Bank

1300 New York Ave.

Washington, DC 20577

USA

E-mail: florencial@iadb.org

\footnotetext{
* The author wishes to thank Francis Teal for very helpful discussions. I also wish to thank Adrian Wood and Simon Appleton who provided excellent feedback on the paper. The paper also benefited from comments received from the University of Oxford's CSAE workshop, the Department of Economics Seminar at the University of Namur, the OECD Development center and the World BankLatin American-Poverty and Gender group seminar participants. All the errors however remain my sole responsibility.
} 


\section{Introduction}

During the past three decades many Latin American countries underwent several macroeconomic shocks and policy swings, ranging from severe inflationary experiences, opening of the economy and privatization to periods of real exchange rate under and overvaluation.

In that context, how the returns to education have fluctuated over these swings remains of central policy concern. Particularly interesting is the exploration of how the dispersion of returns across education levels behaves over time. As rates of return to education are a major determinant of the incentives to invest in education, they are crucial for understanding how individuals change fundamental decisions on schooling, occupational choice, fertility and training with shifts in expected returns. These changing decisions, in turn, might increase the well known welfare costs of macroeconomic fluctuations.

Rates of return to schooling also matter for studies analyzing policy issues such as whether to subsidize different levels of education. Therefore, when cross section evidence is used to inform such decisions, care needs to be taken that the macroeconomic context and dynamics, are also considered.

Several OECD countries have experienced an increasing dispersion of wages during the last two decades, in particular after important structural reforms and, mainly, technological change, globalization and changes in the world demand. By far the biggest rise in wage dispersion took place in the UK and the US (Layard and Nickell 2000). In particular, a large increase in the wage differentials by educational level is observed in these countries (Bound and Johnson 1992, Katz and Murphy 1995, Machin 1996, Schmitt 1995). In the Latin-American context, the case of Argentina is particularly interesting since the increase in wage inequality was larger than in any other Latin American country over the nineties. Moreover, its economic reforms were the fastest and deepest of the region over this period. ${ }^{1}$ Especially, the large variation in macroeconomic aggregates provides exogenous shocks which are sharp enough to constitute natural experiments. ${ }^{2}$

Argentina experienced three important changes in her economic structure during the last 20 years driven by: (i) economic reforms (including trade opening) and higher rates of capital accumulation in the early 1990s, (ii) a medium-sized crisis caused by massive fluctuations in capital flows in 1995 and (iii) a major crisis caused by the inability to maintain the dollar-peso peg that ended up in a $40 \%$ devaluation and default of the debt by the end of 2001. In this context, if individuals are imperfect substitutes in production or they differ in their labour supply behaviour, I assume that these external shocks and policy changes impact differently on individuals wages.

Studies for other Latin American countries have dealt with very smooth time series, so that which shock was causing shifts in wage profiles was difficult to identify. In

\footnotetext{
${ }^{1}$ In 1991 the Argentine economy was transformed through the establishment of a currency board arrangement as part of a set of reforms that altered the monetary system, improved fiscal and tax policies, liberalized trade and reformed the public sector including a rapid privatization programme and changes in the social security system. By the end of 1991, nominal tariffs had been lowered to an average level of $12 \%$ and all import licenses had been eliminated. The physical capital stock (excluding the public sector) grew by $20 \%$ between 1992 and 1999 (Fundación de Investigaciones Económicas Latinoamericanas 2002). The success of these reforms translated into real GDP growth rates of $10.6 \%$ in 1991, 9.6\% in 1992 and always higher- than-5\% rates up until 1997.

2 A precedent to this work is, for instance, Pessino $(1993,1996)$ who uses the natural "experiment" of the hyperinflation period to explore changes in returns to different forms of human capital. Inflation actually went down from $1,343 \%$ in 1990 to $17.5 \%$ in 1992 and to one-digit rates from 1993 until 2002.
} 
this paper I take advantage of the variation in the data to overcome this difficulty and then focus on the evolution of the rates of return to different levels of education. In particular, I correct earlier estimates for selection and attempt to ameliorate the endogeneity problem. I also estimate these non-parametrically and test for different functional forms of the earnings-education relationship. Lastly, I investigate the effects of a set of macroeconomic variables over the returns to human capital during the period 1992-2003 in Argentina's main urban centres. In essence, using household surveys, the objective of this paper is to estimate Mincerian returns and wage premia, by gender and by occupations in a more consistent manner. ${ }^{3}$ In addition to the before and after comparisons common in the literature (Pessino 1993, 1996), I use 12 years of data to determine what period-to-period movement occurred in the economy in stable periods. ${ }^{4}$

Biases due to measurement error in reported schooling, omitted variables, and the distinction between homogeneous vs heterogeneous returns are some of the issues I need to take into account. Moreover, while the standard theory of investment in human capital put forward a concave education-earnings profile, empirical evidence from various countries has challenged the prevailing view (Behrman and Wolfe 1984, Lachler 1999, Blom, Holm-Nielsen, and Verner 2001, Patrinos and Sakellariou 2005, Söderbom, Teal F., and Kahyarara 2006). These estimation issues raise some policy concerns and deserve further investigation.

A number of studies have measured the private rates of return to education in Argentina (Kugler and Psacharopoulos 1989, Pessino 1993, Pessino 1996, Gasparini, Marchionni, and Sosa Escudero 2001, Galiani and Sanguinetti 2003, Fiszbein, Patrinos, and Giovagnoli 2005). However, most of them are dated, constrained by data or have not addressed diverse methodological problems. They mostly compute linear returns to schooling, for males, wage-employees in the Greater Buenos Aires; and hence, are not able to respond to the central question of this study: what happened to the full earnings-education profile, for different occupations in all regions of Argentina over this period dominated by shocks and policy swings?

For instance, Kugler and Psacharopoulos estimate the private rate of return to another year of schooling in a post-hyperinflation year (1989) at 10.3 percent in urban Argentina. They also note that returns to schooling were higher for workers in the private sector.

Pessino (1993), on the other hand, finds that after an inflationary shock, the returns to schooling in Buenos Aires increased from 10 percent in 1986 to 12.5 percent in 1989. Then they dropped to 9 percent in 1990 (a low inflation period) and increased again to 10 percent by 1993. She concludes that hyperinflation caused the 1989 shift in wage profiles.

Gasparini et al (2001) find increasing returns to education on the Greater Buenos Aires from 1986 to 1998, while Galiani and Sanguinetti (2003); and Gasparini and Acosta (2007) find increasing returns to college graduates in the manufacturing sector in Greater Buenos Aires, the main urban agglomeration, over the nineties.

On the other hand, on the effects of crises on the rates of return to education, the literature is relatively scarce. Only Pessino had studied the particular effects of the

\footnotetext{
${ }^{3}$ Differentials in earnings by occupations have not been widely explored besides the report by the World Bank on informality in Latin America (Perry, Maloney, Arias, Fajnzylber, Mason, and SaavedraChanduvi 2007).

${ }^{4}$ This is important as some groups exhibit higher variability over time in their labour market behaviour (i.e informal workers and self-employed have experienced a fall in their wages regardless of the crises).
} 
hyperinflation period their behaviour. Most of the studies from Argentina concentrate on the effects of crisis on welfare, employment, coping mechanisms and use of public services (Fiszbein, Giovagnoli, and Aduriz 2003, McKenzie 2004). McKenzie finds that job exits rose and that exiting workers were not able to increase labour hours worked to counter the effects of existing wages, despite many workers saying that they would like to work more hours. Moreover, in spite of consumer price inflation of $41 \%$, he finds that the distribution of nominal income remained remarkably constant, resulting in dramatic declines in real wages.

The closest work to mine is Fiszbein, Patrinos and Giovagnoli (2005). They estimate Mincerian equations on years of education and on dummies for different categorical levels of education by gender on the full labour force for Argentina from 1992 to 2002 and correct for the selectivity problem in the participation of women in the labour market.

They find that returns to education increase with the level of education. However, they do not attempt to correct for the selection into the labour force for male workers nor for the endogeneity in education, neither explore regional effects or different functional forms of the earnings-education profile.

Summing up earlier work, there are four consistent results from previous studies on Argentina: (i) returns to education increase with the level of education which challenges the dominant theoretical view of concave earnings function (Galiani and Sanguinetti 2003, Fiszbein, Patrinos, and Giovagnoli 2005, Gasparini and Acosta 2007), (ii) men have higher returns to schooling compared to females for every level of education (Fiszbein, Patrinos, and Giovagnoli 2005), (iii) the overall rate of return to an additional year of schooling is higher than the average for middle income countries (Psacharopoulos and Patrinos 2004) and (iv) $10 \%$ of the increase in returns to education seems to be explained by import penetration and wage premia for those workers with complete high school increase more in those industries with higher investment in machinery and equipment. (Galiani and Sanguinetti 2003, Gasparini and Acosta 2007) .

Briefly, three main methods of estimation will be used: (i) standard ordinary least squares (OLS), (ii) Heckman maximum likelihood procedure which deals with the sample selectivity issues which arise because earnings are only observed for individuals who participate in the labour force and who may form a non-random sub-sample of the population, (iii) family fixed effects estimation to control for unobserved family-specific heterogeneity. The latter estimates are based on sibling pairs, grandmother/fathergrandson/daughter and parent-child pairs. In all methods, I add dummies for different occupations and I allow for the possibility that parameters are different for the two genders. At the same time, the main variable of interest (education) will be expressed as one of: levels of education, years of education linear, squared, cubed or flexible (semiparametric specifications). In order to test "credentialism" effects dummy variables for each year of education completed are also included in a different specification.

Another contribution is that I contrast returns to education trends with wage trends, both of which are affected by macroeconomic variables, albeit differently. In some sense I interpret change in returns also as the result of differential rates of change in wages by skill. This is the framework into which I analyse the real effects of shocks and policy swings on earnings by skills.

Finally, I also examine which macroeconomic variable (i.e. GDP, unemployment, etc.) may have affected the time trends in wages at different educational levels.

The rest of the paper is organized as follows: in the first section I briefly discuss the data and show sample means. The second section gives some background informa- 
tion on education, occupations and earnings in Argentina, briefly discussing the main macroeconomic shocks and policy swings over the relevant period. In the third section I outline the empirical framework. The fourth section shows estimates of the earnings profiles and the calculation of rates of return to education for a 12-year period. The endogeneity of education is partly addressed as per the family fixed effects strategy and I control for selectivity in the decision of participate or not in the labour market. I also compute returns by gender, and returns to self-employment vis a vis salaried workers. The fifth section shows additional results in which I estimate different polynomials to check the robustness to changes in the functional form and also include non parametric techniques. In addition, I test whether other segmentation hypothesis (public versus private jobs, occupational effects and firm size effects) might have been factors behind the increasing convexity of the earnings-education profile. In the sixth section, I look at correlations of wages trends with macroeconomic variables, while the last section concludes.

\section{Data and some descriptive statistics}

Earnings equations on the following pages are estimated using all available individual and household level observations from the 1992-2003 May rounds of the Encuesta Permanente de Hogares or Argentine Permanent Household Survey (EPH hereafter). The survey is conducted in May and October each year in urban areas by the Instituto Nacional de Estadísticas y Censos (INDEC). It collects information on labour markets and demographic characteristics at the household level. ${ }^{5}$

The structure of the survey is a stratified rotating panel (25\% of the sample is replaced in each round) and the replacement is made keeping the characteristics from the population of previous samples. ${ }^{6}$

The survey covers 31 urban areas at present, being representative of approximately $62 \%$ of the total urban population (INDEC 2000). ${ }^{7}$ Thus, all the province's capitals and all the cities with more than 100,000 inhabitants according to the Population and Housing National Census of 1991, plus Alto Valle del Rio Negro (an urban-rural center) are covered by the survey. A small but non-negligible fraction of the population resides in rural areas and, unfortunately, relatively little is known about them as the EPH does not have systematic data collection on rural residents. As the year 2003 only has comparable data available for the May wave, I have decided to take only May waves for all calculations. ${ }^{8}$ By doing that, only 13 out of 31 urban areas were left with observations for all Mays between 1992 and 2003, which represents about 50\% of

\footnotetext{
${ }^{5}$ From August 1998 onwards an additional wave was added every August as a way to improve the monitoring of labour market conditions. This 3-waves a year system stopped in 2003 and a "continuous" survey was then implemented.

${ }^{6}$ The primary sampling units are grouped in four rotation groups. Each rotation group is a subsample of size equal to one fourth of the total sample. The rotation is done for each wave such that: in the primary unit (and for each of the four groups assigned by the rotation scheme for that wave) previously selected houses are replaced by new houses. These new houses are selected from the same primary units as the eliminated houses. Therefore, in each wave, $75 \%$ of the houses interviewed in the previous wave will stay in the sample. According to INDEC, this rotation system allows for an efficient estimation of changes at two points in time, avoiding the drawback of attrition (due to the repeated interviewing of the same households).

${ }^{7} 71 \%$ of Argentinas urban population lives in those 31 centres and Argentina urban areas represent $87.1 \%$ of the country, one of the largest shares in the world. While poverty estimates based on the EPH are usually called "national" it should be stressed that the survey only covers large urban centres. The term "urban" refers to towns of 5,000 people or more.

${ }^{8}$ Given that surveys cover only urban areas, most statistics are not affected by seasonality issues.
} 
the country's population. I present in the Appendix the definition of all variables and Appendix tables with a more detailed discussion of the data. Basic statistics of the main variables used in this paper are presented in Table 1.

This table shows that the logarithm of real hourly wages were higher in 2001 than in 1992 as the result of increasing earnings during the first three years of the Convertibility plan and not too large fall in earnings thereafter. The 1995 crisis was reflected in a $2.8 \%$ fall in GDP, even if the upward trend in GDP ended in 1999, when the longest recession of the economy started. GDP finally starts to recover sharply in 2003 catching up with the 1996 level (in Argentine constant prices pesos, AR $\$$ ). The unemployment rate underwent a sharp rise after the first international economic shock in 1995, reaching a rate of $18.4 \%$ and remaining relatively high. ${ }^{9}$

Inequality of real wages has also gone up over the period as illustrated in Table 1 . The proportion of self-employed, wage-employees and managers on the labour force has stayed almost unchanged. Informality has increased and, in spite of various shocks, the Argentine labour force continued to increase its quantity of education and female participation. The latter is one of the main features of the Argentinean labour markets and a concern for selectivity issues. ${ }^{10}$ For instance, increasing activity rates were chiefly pushed up by this phenomenon in the first half of the decade. I explore these issues in more detail in the next section.

\section{Education, occupations, wages and shocks: 1992-2003}

Argentina has one of the most developed education systems in the Americas. Indicators show that despite the recent economic crisis, school enrolment rates are high and drop out levels are low (Parandekar, Espana, and Savanti 2003). ${ }^{11}$ Average years of schooling of the population are 8.5, significantly higher than the Latin American average of 5.9 years. ${ }^{12}$

Argentina also compares well with Eastern and Central Europe and East Asia, where average educational attainment is 8.4 years and 7.6 years, respectively (Barro and Lee 2000). In fact, 16 per cent of the active population had higher education in 2003, while that figure was only 11 per cent in May 1992. And the number of years of education for the full sample had increased by about a year over 12 years, that is a $10 \%$ increase overall, or about $1 \%$ per year (Figure 1 -left panel- and Table 1).

Moreover, the gap between female and male college completers in the labour force has increased by $1 \%$ point. In 1992: $7 \%$ of males in the labour market completed a superior degree while $17 \%$ of the females did so. In 2003 these figures were $11 \%$ and $22 \%$, respectively. This may raise the issue of selectivity in the sample, as it is not only that more females are participating in the labour force, but is the more educated females that might have been self-selecting into the labour market more. There are

\footnotetext{
${ }^{9}$ In fact, Argentina is an exception in Latin America as the variance of unemployment explained by the output gap is only $0.1 \%$, while for other countries is close to 1 (Pages, Busso, Micco, Lora, Panizza, Rodriguez, and Marquez 2004).

${ }^{10} \mathrm{I}$ control for this by estimating earnings and returns to education by gender, but also with Heckman selection models.

${ }^{11}$ Enrolment of 6-14 year-old children is about $100 \%$ all over the period under study.

${ }^{12}$ Argentina's case is also particularly interesting because of the following peculiarities of its schooling system: (i) it is mandatory to attend until high school from 1996, (ii) the government provides education without tuition at all levels, including University, (iii) there is no kind of restriction to the admission to a public school (the only restriction for universities is to have high school level completed), and (iv) private education is available at each level.
} 
also differentials in investment in education across occupations: 18\% of managers, $7 \%$ of self-employed and $12 \%$ of employees completed a superior degree in 1992. In 2003, those figures were: $27 \%, 13 \%$ and $17 \%$, respectively (Appendix Table 11). The most striking is that the education investment gap between managers and salaried increased by $4 \%$ points over this period, while the gap between self-employed and salaried remain unchanged.

In terms of wage trends, the more notable point over this period is the loss in wages of secondary completers: their 2002 (2003) wages were $80 \%$ (65\%) of their 1992 wages; while the wages of primary completers were $84 \%$ (74\%) of their wages 10 (11) years earlier. College completers lost only 5\% (20\%) over this 10 (11) years (Appendix Table 12..$^{13}$

The self-employed have significantly lost compared to other groups both in terms of hourly wages and hours of work. In 2002, the real hourly wages of wage earners were $96 \%$ of their 1992 wages. That figures was only $84 \%$ for self-employed. In 1992 the average total earnings of the latter group were higher than the earnings of salaried workers (mainly due to a higher number of hours worked). While earnings significantly increased for self-employed professionals, labour income substantially dropped for selfemployed workers of low education levels (Appendix Table 13), showing once again that wage differences seem to mainly arise by education level.

Briefly, I study these earnings trends in two distinct periods (before and after 2001) which in turn encompassed four well differentiated sub-periods:

- 1992-1995 ("Economic reforms policy swing"): characterized by massive privatization, opening of the economy, and free-market oriented structural reforms. Low inflation, high growth rates, massive entrances of foreign capital and low real exchange rates ensued these reforms. ${ }^{14}$

- 1995-1998. In 1995 ("1st. external/supply shock"), the Mexican crisis affects Argentina's credibility to back the exchange rate and a massive flow of capital out of the country resulted, together with high increases in interest rates, and decreases in liquidity. As a result, aggregate demand decreased by $2.8 \%$, unemployment increased by 8.3 percentage points, but altogether the 1995 recession was short and positive growth (on average $5.8 \%$ per year) continued until $1998 .{ }^{15}$

- 1999-2002. In 1999 the Russian crisis strongly affects the Brazilian economy (Argentina's main commercial partner) and halted positive growth in Argentina. This sub-period concludes with the 2001-2002 collapse ("2nd. supply shock"), in which a $40 \%$ devaluation of the peso took place, together with default of the country's external debt and a 11\% decrease in GDP (measured in real Argentine pesos, AR \$) in 2002.

- 2003, the last year in my sample shows the beginning of the recovery (8.8\% increase in real GDP) and is my fourth sub-period. However, I will not focus much on this as with only one year available it would not be possible to analyse the medium-long term consequences of the post-devaluation period.

\footnotetext{
${ }^{13}$ I am purposefully reporting figure for 2002 and 2003 because the change in wages between these two years is quite dramatic

${ }^{14}$ This sub-period actually starts in 1991, with the implementation of the Convertibility Plan at the end of the hyperinflation of 1989/1990. Unfortunately, the available data for 1990 and 1991 is not comparable with mine.

${ }^{15} \mathrm{~A}$ set of support measures from the IMF together with different mechanisms of government support to commercial banks helped to stop the 1995 financial crisis and help to restore positive expectations. Because of that, the convertibility regime remained in place.
} 


\section{A model of relative wages determination}

Relative wages in the economy are derived from changes in both derived demand for labour and supply for each type of skill. I assume imperfect substitution among labour types as Pessino (1996), and that increases in demand or supply will change the relative wages. ${ }^{16}$ Following Welch and Freeman (Welch 2003, Freeman 1979) and assuming a CES production function, I have that:

$$
\widehat{W}=(1 / \sigma)(\widehat{d}-\widehat{s})
$$

Where $W$ is the ratio of wages for more skilled or more educated labour with respect to less educated or less skilled, $d$ and $s$ are relative demand and supply respectively for skilled labour, $\sigma$ is the elasticity of substitution for these two types of labour and a hat over a variable indicates rate of change. So, if there is an increase in demand for highly educated individuals relative to supply, I should expect an increase in their relative wage as long as the elasticity of substitution is not infinite. This relative wage increase will be manifested essentially through an increase in the rate of return when one makes the assumption that high skilled people corresponds to highly educated and vice versa.

First, I assume (based on the evidence already presented ) that $\widehat{s} \geq 0$ all over this period (even if different groups might experience differential changes in $\widehat{s} \geq 0$ in times of major crises as I explain later). I then argue that there may be three channels via which I expect macroeconomic variables (shocks or policy swings) to affect $\widehat{W}$.

Firstly, if elasticities of substitution among age groups, experience vs. unexperienced groups, educated vs. uneducated are finite, human capital cannot be treated as a homogeneous input with a single rental price. In this sense, capital deepening, trade and skill biased technological change might change the $\sigma$ parameter. ${ }^{17}$

Secondly, given how the composition of output was affected over this period (via changes in the exchange rate for instance), I can also expect a change in labour demand $\widehat{d}$ that was not uniform across sectors of the economy. I control for this effect by adding sectorial and time dummies in all specifications.

The third channel through which I expect the relative wages of unskilled vs skilled individuals to change differently hinges on the differentiated capacity individuals have to smooth consumption (given their differentiated access either to capital markets or to household insurance) and therefore on how different groups might change labour supply, $\widehat{s}$, and occupation decisions differently. If an individual belongs to a wealthy household, consumption can be smoothed over through transfers between family members. If an individual does not belong to a wealthy household (or if the wealth that used to exist has been depleted or it is not liquid), the whole labour supply decision of the family will change more dramatically.

I expect women of households of this type to increase their labour supply more than men, unless their earnings has been so depressed that the wealth and substitution effect cancel each other out. Decisions of the young and the old will also be altered. In the

\footnotetext{
${ }^{16}$ There is also imperfect substitution between similar educated workers in different age groups. Manacorda et al (2005) show that there was a des-acceleration of the growth rate of educational attainment across cohorts (i.e change in relative supply of highly educated workers across age group lower than the relative supply change) in Latin-America.

17 Galiani and Sanguinetti (2003) take the data for the manufacturing sector and introduce import penetration and investment in machinery and equipment variables for individual $i$ working in sector $j$ and interact it with the level of education of individual $i$ in order to test this hypothesis fully. Gasparini and Acosta (2007) do so by introducing data on machinery and equipment at the sector level.
} 
case of the young, where more fundamental investments decisions are being taken, the whole human capital accumulation decision may change labour supply. If they belong to a wealthy household, they will probably increase their investment in schooling (if real wages are depressed); although the expected rate of return to education will also affect their schooling decisions. With respect to the old, I expect to find increases in labour supply for the less wealthy and those who do not have children, or whose children are unable to support them. ${ }^{18}$ Unfortunately, as wealth variables are not available in the data I cannot explore this relationship. Still, I use as proxy the size of the household, which also serves as a variable that might capture the ability of a family to smooth consumption. Given this lack of precise data, selection issues are going to be crucial to understand changes in participation in the labour market, Heckman models will be estimated using various determinants of the reservation wage as exclusion restrictions (head and married status dummies, number of children in the household and household size). The effects that operated after the 1998-2001 crisis might have been particularly driven by selectivity bias. Moreover, the selection term (Mills ratio) can also be informative about the process of selection after a crisis.

Lastly, another aspect (that could affect elasticities and smoothing) is the sorting across firms, occupations, sectors and schools. Fafchamps et al (2006) show how much of the total returns to education in Africa is due to sorting across firms and across occupations within firms. Also see Soderbom et al (2005) for an investigation of the relationship between earnings and firm size.

The existence of an inter-industry wage premium has also been well documented (Dickens, Katz, and Lang 1986, Krueger and Summers 1989). In another paper, Katz argues that much of the shift in relative demand in the US can be accounted for by observed shifts in the industrial and occupational composition of employment toward relatively skill-intensive sectors, the majority reflecting shifts in relative labour demand occurring within detailed sectors. These shifts are likely to reflect skill-biased technological changes (Katz and Murphy 1995). I partly account for this with sector fixed effects estimation.

Another source of heterogeneity I will not be able to address due to the lack of data fro the whole period is the type of school these individuals have attended (this information is available from 1995 onwards only). Andres uses a shorter time span and shows that workers educated in private schools have higher returns than those in public schools and the quality of schooling significantly affects returns (Andres 2003).

Is in this theoretical framework, together with the preliminary empirical evidence just provided, in which I want to answer the following questions: How do returns to education change in a middle income economy, dominated by wage employment? What has been the implications of increasing supply of education for the returns to education in this economy? Also, how have economic reforms and different types of shocks changed the returns to education and to different occupations? Now I turn to the baseline model of earnings.

\footnotetext{
${ }^{18}$ Actually, unemployment rates rose between 1992 and 1998 partly due to the fact that spouses and youngsters decided to start seeking for a job ("added- worker effect"). This fact suggests that part of the causality could have been from inequality to unemployment: the drop in wages of low-income household heads triggered a jump of their relatives from home to the labour market, a fact that could have fed the increase in unemployment.
} 


\section{Earnings model and identification strategy}

\subsection{Basic equations}

One of the aims of this paper is to consistently estimate the earnings-education profile, and to investigate if there is any evidence of changes in that profile that has been affected by shocks or policies over time. For that purpose the baseline model is based on Mincer equations (Mincer 1974). I expect the beta coefficients for the educational levels and the time variable to reflect how aggregate changes did impact differently on wages of different individuals. Despite the increasing evidence of convexity in the earnings-education relationship, Mincerian returns remain popular and have been widely estimated. I start by estimating the by-levels function specified here below by year: ${ }^{19}$

$$
\begin{aligned}
\ln W_{i t}= & \alpha+\beta_{0} \text { male }_{i t}+\beta_{1} \text { age }_{i t}+\beta_{2} \frac{\text { age }_{i t}^{2}}{100}+\beta_{3} \text { Pric }_{i t}+\beta_{4} \text { Seci }_{i t}+\beta_{5} \text { Secc }_{i t} \\
& +\beta_{6} \text { Supi }_{i t}+\beta_{7} \text { Supc }_{i t}+\text { urbanareaD }+ \text { less } 18 D+\mu_{i t}
\end{aligned}
$$

For the estimation of this model, the dependent variable is the log of hourly real wages (at 1998 prices). The independent variables are age, $\frac{a g e^{2}}{100}$ which is the squared of age by 100 (to facilitate interpretation), Pricit $, S e c i_{i t}, S e c c_{i t}, S u p i_{i t}$ and $S u p c_{i t}$ refer to dummy variables for: primary complete, secondary incomplete, secondary complete and Superior (including college) incomplete and complete, respectively (Prii $i_{i t}$ is primary incomplete or no education and is the omitted category). 13 urban area dummies and a dummy for those 14-18 year old are always included but not reported for simplicity in exposition. Regressions are performed either by year or year dummies are included. Finally $\mu_{i t}$ is the error term and $i$ and $t$ denote individual and time respectively.

Another specification includes a quadratic function of potential experience instead of age. Another one adds tenure dummies, a dummy for self employment (interacted with education to capture the heterogeneity of this group) and a dummy for informality.

I therefore did not include in equation (2) variables that may be channels through which education affects earnings, e.g. firm size or sector. In one specification shown in the first Appendix Table, I add firm size, a dummy for whether the person works in the public sector, sector and occupation dummies because I want to see how much is captured by those variables. Finally, I also estimate equation (2) on the pooled data including time dummies and interacting those time dummies with education dummies (in order to capture the education-and-time-variant effect), as in the specification shown below.

$$
\begin{aligned}
\ln W_{i t}= & \alpha+\beta_{0} \text { male }_{i t}+\beta_{1} \text { age }_{i t}+\beta_{2} \frac{a g e_{i t}^{2}}{100}+\Sigma_{g}\left(t * D S_{i g t} * \beta_{g t}\right)+\beta_{t} t+ \\
& + \text { urbanareaD }+{\text { less } 18 D+\mu_{i t}}^{\text {urbanat }}
\end{aligned}
$$

where $t$ is time, $D S_{\text {igt }}$ is a dummy variable that indicates a schooling group $g$ in period $t$ and $\beta_{g t}$ is a schooling effect in period $t$ (time-varying returns to education). ${ }^{20}$

\footnotetext{
19 This is the same specification as Gasparini (2001). However, he performs this regression on the sub-samples of heads, spouses and others members of the household between 14 and 65 year-old in order to account for sequential participation in the labour market (that is, spouses choose to participate after knowing the decision of the head to participate, etc).

${ }^{20} \mathrm{I}$ did not interact age/experience variables with time as my results from estimating equation $(2)$ showed there was no statistically significant change over time in those variables' point estimates. Therefore, I take these variables at their average level in this equation.
} 


\subsection{Rates of return to education}

Rates of return to education will be defined here as the Mincerian returns, or wage premium (Mincer, 1974). In the case of the log-lin specification in equation (2), the returns per additional year of education will be defined as follows:

$$
\begin{aligned}
& \operatorname{RoR}(\text { Pric })_{t}=\left[\exp \left(\widehat{\beta_{3}}\right)-1\right] / S_{\text {Pric }} \\
& \operatorname{RoR}(\text { Seci })_{t}=\left[\exp \left(\widehat{\beta_{4}}\right)-1\right] / S_{\text {Seci }}-S_{\text {Primc }} \\
& \operatorname{RoR}(\operatorname{Secc})_{t}=\left[\exp \left(\widehat{\beta_{5}}\right)-1\right] / S_{\text {Secc }}-S_{\text {Seci }} \\
& R o R(\text { Supi })_{t}=\left[\exp \left(\widehat{\beta_{6}}\right)-1\right] / S_{\text {Supi }}-S_{\text {Secc }} \\
& \operatorname{RoR}(\operatorname{Supc})_{t}=\left[\exp \left(\widehat{\beta_{7}}\right)-1\right] / S_{\text {Supc }}-S_{\text {Supi }}
\end{aligned}
$$

where $S_{\text {Primc }}, S_{\text {Seci }}, S_{\text {Secc }}, S_{\text {Supi }}$ and $S_{\text {Supc }}$ are the total number of years of schooling for each successive level of education. In the Argentine case these are (not considering drop outs case): 7, 10, 12, 15 and 17, respectively. For instance RoR(Primc) $)_{t}$ would be the return to Primary complete over Primary incomplete or no education (which are drop outs). I report these returns by levels of educations in the next section for different specifications of earnings models (naive, corrected by selection and familyFixed Effects). ${ }^{21}$

\subsection{Rates of return to self-employment}

Many models suggest that earnings functions should be estimated separately for employees and self-employed. An earnings function as in equation (2) with a dummy variable for self-employment or formality provides a direct estimate of relative occupational earnings differentials but imposes identical rates of return to all explanatory variables for both occupations. When estimating earnings functions it is necessary to avoid selection bias. Incomes are observed only in the occupation an individual chose to participate in; and those who participate in self-employment might not be a random sample of the population. Without correcting for this, the estimated coefficients will be biased. It is possible to remove selection bias (Heckman 1979) estimating two equations. First, the participation equation $z_{i}=\alpha Z_{i}+\nu_{i}$, where $\mathrm{z}$ is an indicator equal to one if individual $i$ is self employed and 0 otherwise. $\mathrm{Z}$ is a set of explanatory variables that explain participation and $\nu$ is a disturbance term. Second, having computed fitted values, $\widehat{z}$, from this regression, the inverse mills ratio $\lambda=-\frac{\phi(\widehat{z})}{\varphi(\widetilde{z})}$ is added to the right hand side of the earnings function 2 , where $\phi($.$) and \varphi($.$) are the density and cumulative distribution$ functions of the standard normal distribution. If the coefficient on $\lambda$ is positive, that means positive self-selection into self employment. The finding of positive selection bias for self-employed would suggest that the distribution observed for the self-employed is higher than would be found for comparable workers who chose salaried work.

The empirical regularities are: first, that rates of return to schooling tend to be lower for self-employed, consistent with the idea that entrepreneurial skills are nonacademic in nature ${ }^{22}$; second, self-employed have flatter earnings-age profile than the

\footnotetext{
${ }^{21}$ I do this for two samples: the full sample, and the family-tied sample as I describe later

${ }^{22}$ For Argentine data: a wage employee with less than completed high-school level of education will have substantial higher returns than a self-employed, however that differential does not exist for those at the top end of the distribution. Additionally, returns to wage-employees college graduates' rise steadily, while the returns to self-employed college graduates' react more to changes in the macroeconomic conditions, consistent with this observation. Regression results available upon request.
} 
salaried, in line with the agency-cost model of Lazear and Moore (1984); third, few explanatory variables posses much explanatory power on self-employed regressions and last, on sample selection, the direction of the bias is in disagreement. There is no clear-cut evidence that self-employed self select into self-employment because they have comparative earnings advantage there; in contrast many find positive selection into wage employment (implying that the self-employed would earn more if they become salaried).

\subsection{Semi-parametric estimations, polynomials and the dummy vari- able approach}

So far, there were no studies to my knowledge, trying to assess the impact of relaxing the "constant-education-slope" assumption commonly maintained in the literature, beyond the by-levels regressions. In this paper that assumption is explored further; and overall, my results cast doubt on the accuracy of constraining education to have an homogenous impact in earnings equation still common in the literature.

Therefore, in order to grant more freedom to the relation between the variables and to allow for non-linearities in the education-earnings profile, I use the continuous variable $S$ (years of completed schooling) and estimate this function semi-parametrically . I use the partial linear regression model first suggested by Yatchew (1997). This estimation combines parametric with non-parametric techniques, by implementing a differencebased algorithm.

As particular cases, I estimate polynomials (square and cubic) and the Dummy Variable Approach (one dummy variable for each year of education completed ( $\mathrm{S}=1,2$ ...19).

The basic polynomial equation (for the pooled data) is:

$$
\ln W_{i t}=\alpha+\beta_{1} a g e_{i t}+\beta_{2} \frac{a g e_{i t}^{2}}{100}+f\left(S_{i t}\right)+\beta_{t} t+\text { urbanarea } D+\mu_{i t}
$$

Here I introduce non-linearity via $f\left(S_{i t}\right)$; where $f$ is a smooth, single valued function with a bounded first derivative. In this model the parametric, $X \beta$, and non-parametric, $f\left(S_{i t}\right)$, parts are additively separable.

The dummy variable approach, in contrast, gives a function that "jumps" each time one moves from one level of education to another. This provides for a test for credentialism.

\subsection{Endogeneous education: an attempt to ameliorate the identifica- tion strategy}

It is widely recognized that using OLS to estimate returns to education from cross sections is problematic. Education can be correlated with the earnings residual due to unobserved ability. ${ }^{23}$ And it could be that unobserved ability is correlated with the returns, I therefore attempt to somehow allow for this endogeneity in section 4 . As is common knowledge, the OLS estimator will give biased estimates of the returns to education if education is endogenous and also if there are sample-selection issues.

\footnotetext{
${ }^{23}$ Measures of IQ do not exist in Argentina, here I am concerned therefore about the unobserved family background effects via genetics and common background on education.
} 
The common concern is that education could be correlated with unobserved labour market ability, and then returns would be upward biased. ${ }^{24}$ Potential instruments to correct for endogeneity are variables that are correlated with education and uncorrelated with the earnings residual. Family background variables have been used as instruments for education in many previous studies, primarily on the grounds that such variables should have no causal effect on earnings. Social and natural experiments are also useful and many studies using institutional variations in schooling due to such factors as proximity to schools, minimum school-leaving age and others have been used to instrument for schooling. Card $(1995,1999,2001)$ provides a summary of some of the recent studies that use this approach and include Angrist and Krueger, Butcher and Case and Card (1991, 1994, 1995b, 1995a) among others. In all waves in my data there is information on parent's education for the sub-sample of youth still living with their parents at the moment of the survey. The percentage of less-than-30 living with their parents is about $75 \%$ when taking all individuals, but it is $47 \%$ when taking the employed between 14 and 30 year-old. Due to this severe selectivity, I have discarded this strategy.

An alternative to the IV technique is to either use repeated observations on the same individual over time or observations from different individuals within the same family to difference out the variables generating correlation in the residuals in a fixed effects approach (Ashenfelter and Rouse 1998, Ashenfelter and Zimmerman 1997). Arguably, a good part of the unobserved heterogeneity is common to family members. Here the argument is one of genetic endowment and common "experience". Since individuals linked by family affiliation are more likely to have similar innate ability and family background than randomly selected individuals, this procedure provides a straightforward control for unobserved family attributes, though results might be open to alternative interpretations (because of assortative mating in marriage markets, for instance).

Consequently, differences in unobserved ability and their impact in determining education should be lower within rather than between families. Earnings functions can be estimated on siblings, father-son or mother-daughter pairs using a fixed effects or first-differencing approach. By introducing sub-samples of households with at least two individuals in employment (and more stringently households with brothers/sisters, father-son or mother-daughter pairs in employment) the fixed effects method effectively controls for all household variables that are common across these individuals within a given household. Therefore, as a by product, besides estimating unbiased returns to schooling, I will also see whether the correlation between earnings and schooling is due, in part, to the correlation between family background and schooling. ${ }^{25}$

A simultaneous advantage of the fixed effects procedure is the elimination of the sample selection problem (Pitt and Rosenzweig 1990).

\subsection{Channels via which macroeconomic variables affect relative wages}

Standard human capital models of the education-earnings profile which posit that earnings rise with education, age or experience solely as result of individual investment behaviour are incomplete. For instance, difference in the activities ( $\sigma$ in equation (1)); and changes of activities over time of different type of workers $(\widehat{s})$ and in the demand

\footnotetext{
${ }^{24}$ A common finding in the empirical literature is that estimated returns rise as a result of treating education as an endogenous variable (Card 2001).

${ }^{25}$ As a robustness test, I took an index of characteristics of the house (i.e. house type, number of shared/non-shared rooms, tenancy agreement) as a wealth proxy which is not supposed to have causal effects on earnings. This was used as instrument for education. Results are available upon request.
} 
for those activities $(\widehat{d})$ decisively influences the shape of that profile. Macroeconomic shocks certainly affect these three things.

First, macroeconomic shocks can affect cohorts differently depending on how the shock changes $\sigma$ (the rate of substitution between educated and uneducated workers). The main assumption in the literature is that groups of workers categorized under some definition are different factors in the production function. ${ }^{26}$ Therefore, if there is a technological shock that substitutes unskilled by skilled workers (i.e. in the CES function $\sigma$ goes down), we should observe an increase in relative wages of the skilled.

Secondly, changes in relative demand of labour, $\widehat{d}$, are very likely to have affected relative wages during the nineties. For instance, the consensus is that in developed countries there has been a shift in demand away from unskilled labour in favor of skilled workers during the last two decades. The two explanations for this shift are: the impact of trade with low-wage (developing) countries, and skill-biased technological change (Berman, Bound, and Machin 1998, Machin 1996, Wood 1995, Galiani and Sanguinetti 2003). I provide some correlation analysis between employment and import penetration in the last section and I explore both channels-hypotheses (changes in $\sigma$ and $\widehat{d}$ ) fully in another paper.

Lastly, crises certainly may have also affected the way wages were bargained (mostly in the informal-salaried and the self-employed sector). Moreover, the devaluation and inflation in 2001 may also have played a role in increasing the wage flexibility, probably more for the self employed and the informal employees, besides changing the participation rates from women, or different socio-economic groups (the poor, the old, blue/white collars, as exposed in "third channel" in Section 2). I look at the evolution over time of the self-employment dummy and the informality dummy to address the first issue in a before-and after crisis framework. I also control for selection year-by-year and include sector fixed effects; to account for changes in the composition of labour supply and occupations $(\widehat{s})$.

In this paper I do not estimate these effects directly. I am rather interested in the before and after 2001 comparison of rates of return, as my identification strategy relies on the the 2001/2002 crisis as a natural experiment. However, I cover some of these issues by correcting by selection. And also, very briefly, in the last section I am interested in identifying the particular macro trend behind the changes in relative wages over the nineties. I start by looking at the correlation between GDP, unemployment and wages for different skill levels.

\section{Estimates}

In order to predict the effects of macroeconomic variables on the structure of wages I proceed in the following manner: first I present the estimated wage equations by level of education and then by gender, as well as the returns to self-employment; together with the calculation of returns, controlling for selection, endogeneity and analyzing the functional form. Second, I see if the effects of shocks or economic reforms show a consistent pattern; that is whether effects encountered in the early nineties (opening of the economy and structural reforms), 1995 (financial crisis) or after 1999 (recession

${ }^{26}$ This assumption also applies to the rate of substitution between experienced and unexperienced workers, different expectations about their level of future wealth, and the time in their life cycle at which the different shocks occurred. However I do not concentrate on these here. 
followed by collapsing GDP and devaluation) are really "outliers" from otherwise smooth series on the rate of return to different human capital arguments.

\subsection{Wage profiles}

I take year 1992 and primary incomplete workers as the base year/category and estimate a Mincer regression as equation (2) adding year fixed effects and a male dummy to capture the gender effect in Table 2. From this table I have predicted the average real earnings trends by education level, which are shown in the right panel of Figure $1 .{ }^{27}$ After controlling for age/experience and urban area fixed effects, predicted wages show a positive trend for every education level until $1994 .^{28}$

For college graduates in particular, wages recover from a fall in 1996 and rise up until 1999. Their wages then stagnate until 2001, fell by $18 \%$ in 2002 (with respect to 2001) and kept falling until 2003. The overall fall sums up to a total of $11 \%$ over the whole period. For secondary completers, wages decreased between 1995 and 2001. Only in the crisis year, their wages fell by $21 \%$, adding up to a total fall of $45 \%$. The crisis also hit primary completers harshly (-23\% change in 2002 and $-41 \%$ overall).

A particular feature of the medium-sized-crisis year (i.e., 1995) as opposed to the 2002 crisis, is the data showing that the more the stock of general human capital, the less was the impact of the shock in real wages (see interaction of the college completer dummy with time in contrast to other levels of education in Table 2). Education may thus have well served as a tool to secure a better job, and therefore better earnings. ${ }^{29}$

Table 3 replicates the information of the right panel in Figure 1 in a disaggregated manner: one component due to time and another due to education. The time dummies show the effects of shocks that are not explained by any of the explanatory variables included. The time trend in column (1) reflects the common downward trend in wages (which is statistically significant). The trend by education level (columns (3), (5) and (7)) shows secondary completers as the big losers of the period, mainly due to the losses they suffer over the last part of the decade. There is also a statistically significant negative trend for secondary incomplete workers over time (not reported), then followed by primary completers and drop outs.

Overall, these figures suggest that after a crisis, all educational categories seem to lose equally. However, the type of crisis matters, as the average loss was about $5 \%$ in 1995; and about $20 \%$ in 2002.

Lastly, the left panel of Figure 2 shows predicted earnings by occupations, after controlling for self-selection into each occupation (based on Table 4). Wages increase for both occupations until 1994, while over the first crisis in 1995, self-employed see their wages decrease much faster than wage-employees. In the next two years, and in spite of the recent start of the recession, wages increase for managers and self-employed, while earnings of wage employees stagnate and those of the informal waged workers kept

\footnotetext{
${ }^{27}$ Results of the specification using potential experience instead of age and adding tenure dummies in equation (2) are available upon request.

${ }^{28}$ The upward trend in wages started in 1991 . The implicit increase in wages brought about by the low real exchange rate in 1991 was aggravated when considering the relative price of capital goods versus labour, since wages continued to be taxed at high rate, while investments in physical capital become cheaper through basically zero tariffs to the imports of intermediate capital goods. When one considers labour in the aggregate, this increase in its relative price, should imply a decrease in labour relative to physical capital demand. The relative price of labour increased by $40 \%$ between 1990 and 1993 according to the Economic programming Secretary (Secretaría de programación Económica).

${ }^{29}$ Probit regressions, that show that a higher education is associated with a higher probability of employment, are available upon request.
} 
falling (not reported). In summary, wages for both occupations have a decreasing trend from 1995 onwards.

The largest gap in earnings across occupations occurs between self-employed secondary and self-employed college graduates. This is consistent with the fact that the self employed are a very heterogenous group that can range from street vendors who use small amounts of physical capital to an entrepreneur producing goods with varying amounts of equipment. The gap between categories only starts increasing in 1995, because of hourly wages for both the self-employed and informal workers falling faster than those of the wage employees (see the decreasing coefficient of the self-employment dummy in Table 4). From 2001, however, there is a very similar rate of change in wages across occupations.

\subsection{Rates of return}

Overall rates of return Overall, the returns to primary schooling remained almost unchanged and small during this decade (not reported). As shown in the Table 5 . both wage-employees and self-employed get, on average, 2 to $3 \%$ higher earnings per additional year of education than someone with primary incomplete. This is the expected result for an economy with universal primary education and with a very small and aged proportion of uneducated employees in the labor force. Therefore, returns to primary education appear of only historical interest here. The returns to complete secondary schooling remained largely unchanged. ${ }^{30}$ The returns to university education (complete or incomplete) increased dramatically over the period (from 34\% in 1992 to $45 \%$ per additional year of education in 1998 by means of the fixed-effects estimation). This trend was true for both samples (full and family-tied). More importantly, this shift was robust to part of the unobserved family heterogeneity and to selection. ${ }^{31}$

Results in the columns labeled "HECK" come from the estimates in Table 7 (top panel) and correct for selection bias by using the Heckman maximum likelihood procedure and incorporate lambda into earnings functions estimates. The selectivity-corrected earnings functions reported include the standard variables -education, age and its square and the urban area dummies. Household demographic variables (hhead=1 if household head, married $=1$ if married or living together, numchild $\mathrm{HH}=$ number of child in a household) are used as exclusion restrictions; these variables are believed to determine participation in work but do not directly affect labour market earnings. All are individually statistically significant. In terms of the Mills ratio, the negative (and increasing) selection found for those with positive wages suggest that the wage distribution for paid workers is lower than would be found for comparable workers who chose not to participate. Moreover, the Mills ratio increases steeply just after the start of the 1998 recession, which might imply that after a dramatic fall in labour demand, more skilled (but also more able or richer) workers do drop from the labour force. ${ }^{32}$

\footnotetext{
30 Margot (2001) shows for Buenos Aires for the period 1980-1999, that workers with secondary incomplete experience stable returns (on average $12 \%$ although decreasing in recent years, reaching $10 \%$ in 1999). Workers with secondary complete experience slightly higher returns (13\% on average and reaching $11 \%$ in 1999). The small differences with my figures are due to a different definition of returns and to him considering only the Buenos Aires area.

${ }^{31}$ This result holds, at least, for the sub-sample of all those families that included individuals with one or more family ties within a household.

32 This feature (relative shortage of skilled workers in times of falling wages) might be one of the reasons behind the post-recession increasing returns to education. I hope to come back to this point in future research.
} 
Importantly, the return to college graduates' education remains significantly increasing relative to those with secondary education or primary education even after controlling for selection bias. However, the magnitude of these returns fell for every year after the Heckman correction.

On the other hand, the results in the columns labeled "FE" show estimates based on Table 8. These are lower than the OLS estimates, a finding consistent with previous literature. Rates of return can be biased upwards by up to $20 \%$ (i.e., year 1992) by the omission of family background factors. Some part of the attenuation could be due to measurement error. However, the FE findings confirm that the convexity of the education-earnings profile is not an artifact of some unobserved family heterogeneity. I have two qualifications to add: first, the gap between secondary and primary returns, instead of staying stable now slightly goes down (particularly after 1995). Second, the gap in the Mincerian returns between college completers and secondary completers shows the same increasing trend that stops in 1998. However, the magnitude of the change from 1998 to 2002 is larger in the FE estimation than the others.

Briefly, this is only suggestive evidence of the increasing convexity not being fully explained by any sort of shifts in the distribution of ability or common experience within families nor serious selection in this population, but rather by actual changes in premia to schooling, at least from 1992 to 1998.

Rates of return by gender Results in Tables 6 and the bottom panel of 7 demonstrate that rates of returns to education for men are higher than for women, at every level, consistent with Patrinos' findings (2005) and also confirming the reversal of the trend found in the 1980's and 1990's for the Greater Buenos Aires (Psacharopoulos 1994). ${ }^{33}$ The male dummy actually shows that males are receiving, on average, $10 \%$ higher earnings than females from 1992 to 2003.

Among secondary completers, men experience a decreasing trend until 2001, but after the crisis their returns raise again; while for women, these have stayed flat. Returns for both males and females rose steadily among college graduates.

Moreover, the Mills ratio is positive for the women's equation which implies positive selection bias in women's employment. The finding of positive selection bias for women suggests that the wage distribution observed for paid women is higher than would be found for comparable women workers who chose not to participate. This is coherent given with the increasing levels of women's education shown in the descriptive statistics. Moreover, the increasing trend of the Mills ratio until 1996 is correlated with the observed rising trend in female participation; however, after 1996, there is no clear trend in the Mills ratio.

Rates of return to self-employment Results in Table 4 show the statistically significant declining returns to self employment year-after-year. These coefficients are also economically significant as they show that in 1992 a self-employed individual will earn 9 per cent less than a wage-employee while ten years later, he will earn 31 per cent less than a waged employee.

The finding of negative selection bias for self-employed, by means of the Mills ratio, would suggest that the distribution observed for the self-employed is lower than would

\footnotetext{
33 Psacharopoulos found that in 1985 , returns to schooling were $9.1 \%$ for men and $10.3 \%$ percent for women; and in 1989, $10.7 \%$ for men and $11.2 \%$ for women. More recently, Patrinos et al find that returns to schooling in 2002 is $12 \%$ for men and $10.8 \%$ for women, very close to my estimates for 2003 .
} 
be found for comparable workers who chose salaried work. This finding point towards the fact that unmeasured characteristics which affect the choice of work activity also influence the wages of the self-employed. These characteristics may, for instance, include the inability/dislike to work in a structured work environment and/or attitudes towards risk.

Internal rate of return The rates of returns above are calculated as private returns (i.e., considering private benefits and costs). I have therefore not included the cost for society for education provision (i.e., teachers salaries, infrastructure expenses, etc.) because unfortunately data is limited. Also, the available earnings are pre-taxes earnings because there is no information on after-tax earnings in the EPH. The calculated Mincerian rate of return to education will be equivalent to the internal rate of return (IRR) under two assumptions: (i) first that the differentials in earnings between, say, the college and the secondary completer workers stay constant over time; and (ii) the only cost of continuing education is the opportunity cost measured as the non-perceived wages during that period.

Therefore, the IRR cannot be calculated as, for the period under study, there is no information on direct costs (fees, materials). They could be calculated from Expenditure Surveys, but these surveys are too recent and would not be appropriate to estimate the 1992-2002 period. Besides, given that education in Argentina is public and therefore free ${ }^{34}$, one could assume that direct costs have a very small participation in total costs. Given the above, assumption (ii) can be taken as a good approximation to reality.

\section{Robustness test: functional form and segmentation hy- potheses}

\subsection{Semi-parametric estimation}

The right panel of Figure 2 summarizes the evidence presented in the last section using semi-parametric estimation techniques, and provides further validation for the statement that increasing convexity in the earnings-education profile was a novel feature of this economy over the nineties and early 2000's. More importantly, that increasing returns were different in nature before and after the 1998-2002 recession/shock. Following Yatchew (1997) I used the Stata routine lowess to generate the non-parametric smoothing of a non-linear function, $f(S)$, that illustrates the non-parametric estimates of the return to an additional year of education in three selected years: the start of the period under study, the start of the recession and the major crisis.

\subsection{A note on polynomials and the dummy variable approach}

Both the square and the cubic function (not reported) are mostly well accepted by the data. However the cubic shows higher levels of significance. Results by year, gender and by occupation are not reported, but available upon request. The signs of the coefficients display as expected (positive for the linear, negative for the square and positive for the cubic). The dummy variable approach (not reported but also available upon request), also confirms that there has been a significant shift in the earnings-education profile.

\footnotetext{
${ }^{34}$ Even if there are private institutions that do have fees, there is always the option of going to a public (and free) school.
} 
However, there are no "jumps" effects which is in line with the work by Patrinos and Savanti (2005) which found little evidence of screening or credentialism driving the returns to schooling in Argentina.

\subsection{Other hypotheses}

Results for the specification with controls for segmentation and the size of the household are presented in the Appendix Table 10. When controls are introduced for firm size, a public sector job dummy, number of persons in the household (a proxy for either wealth or the ability to smooth consumption) and sector fixed effects there is a significant decrease in the college education coefficient in all specifications. Therefore at least part of the wage-gap can be explained by other reasons than human capital. There are perhaps higher returns to workers in larger firms, high-paying industries, private sector jobs and smaller households. For instance, the estimated elasticity of wages with respect to firm size of 0.03-0.04 shows that if firm size doubles, a worker will receive ceteris paribus a 3 to $4 \%$ wage increase. Sector fixed effects dummies are also statistically significant. Additionally, I introduced occupations fixed effects with and without sector effects and the main result (increasing convexity in the earnings-education profile) remains unaltered. ${ }^{35}$

These results clearly suggest that the size of estimates of the returns earlier should be taken as noisy estimates of the actual rates of return. I explore in the next section what macroeconomic variables might have played a role in the observed increasing gap between secondary and college completers.

\section{The effects of macroeconomic variables on wages by skills}

There are two main plausible hypotheses presented in the literature for the trends found in this paper: trade and skill-biased technical change. ${ }^{36}$ In Latin America, indeed it has been observed that relative demand for secondary-educated workers has been going down over the period (Sanchez Paramo 2002, Perry, Ferreira, and Walton 2004). However, no literature has established a direct test for the causes behind that change in relative demand. Galiani and Sanguinetti have shown that import penetration rose the most in sectors intensive in technology (Galiani and Sanguinetti 2003), which opens the question of whether trade alone or in combination with skill-biased technical change has been the responsible for increasing wage inequality. On the other hand, Gasparini and Acosta (Gasparini and Acosta 2007) find that the wage premia for those workers with complete high school increase more in those industries with higher investment in machinery and equipment. ${ }^{37}$

\footnotetext{
${ }^{35}$ The occupation effects are dummies for: professionals, white collars (calificados or qualified/highskilled) and blue collars (semi-calificados and no-calificados, that is semi-skilled and unskilled workers).

36 Over the 1980s and 1990s, Argentina together with other Latinoamerican countries have contradicted the traditional wisdom in terms of openness to trade and wage inequality. Evidence from these countries (Wood 1997, Robbins and Menendez 1995) show that increased openness has widened wage differentials in the early nineties. On the contrary, the experience of East Asia in the 1960s ad 1970s supports the traditional theory (i.e. greater openness tends to narrow wage inequality between skilled and unskilled workers). It has to be noted that at the time when Latin American countries liberalised, they were no longer unskilled-labour abundant, as opposed to East Asian countries which liberalised when they were unskilled-labour abundant.

37 Also, see Gould, Moav et al (2001) for a model that endogenously generates the patterns of wage inequality and educational attainments seen in the last few decades in some developed countries (and in Argentina). Their model is based on the disproportionate effects of technological changes on the
} 
In Table 9 I take a different direction and show regressions of earnings by levels of education on GDP, one period-lagged unemployment and a time trend for a preliminary exploration of the effects of macroeconomic aggregates on wages. ${ }^{38} 39$

There is a positive but regressive effect of GDP on wages with a wage-GDP elasticity of 1.114 for primary completers versus a wage-GDP elasticity of 1.407 for college completers (i.e, if GDP doubles, earnings will go up by 111 and 141 per cent, respectively, showing a gap of 30 percentage points). One-period lagged unemployment is statistically significant and negatively related with wages. The latter seems to affect more the secondary completers (i.e. if lagged unemployment were to double, their earnings will fall by 22 per cent) followed by the primary and then college completers, consistent with the findings on wage loses (the three coefficients are significantly different: t-tests are available upon request). The time trend is economically and statistically significant and negative for all levels of education: while college completers have seen their wages decrease by 2.1 per cent a year, primary completers experienced a 4.2 percent fall each year. ${ }^{40}$

Results in this section are very preliminary evidence of the effect of some macroeconomic variables in wages by skills. Given the statistical and economical significance of both unemployment and GDP variables in these regressions one certainly needs to further explore labour demand hypotheses.

\section{Conclusions}

There are four main empirical findings in this paper. First, I find that until 2001, increasing convexity in the earnings-education profile reflects increasing or stable earnings for college graduates combined with decreasing earnings for the less educated from 1995 onwards. However, after the 2001 crisis, the increasing premium to education results from the wages for the less educated falling at a faster pace than college graduates'. This result is robust to family fixed effects (which addresses partly the endogeneity problem), selectivity and to changes in the functional form (including parametric and semi-parametric techniques). As found in previous literature, OLS estimates of returns to education are upward biased when not considering family background variables and the bias can be of up to 20 per cent. Semi-parametric estimation shows that from 1992 to 1998, increasing returns are mainly driven by increases in wages at the top of the distribution while after the recession-crisis period, the increasing returns are driven

depreciation of general versus technology-specific skills, and the resulting precautionary factor in the demand for general education which guards against the higher depreciation risk of technology-specific skills (Gould and Weinberg 2001).

38 Data was only available for 1992-1999 for other interesting variables, such as import penetration ratios (measured as imports over valued added by sector) and capital accumulation (measured as gross investment in machinery and equipment over valued added by sector). I also tried other macroeconomics variables, namely employment, sub-employment, exchange rate and the growth rate of all of them. The only statistically significant results were for the variables left in the tables here reported.

39 Demographic and occupation variables are included but not reported. Results show that the age profile has the expected sign, the male dummy reflects an interesting pattern in which more educated females are hurt by gender wage inequality more than the less educated ones. The previously observed negative coefficient for self-employed is also present by education levels, but differences in the coefficient by skills are sizable: the coefficient for the secondary completers approximately doubles the one for primary completers and it is seven times the coefficient for college completers, with these differences being statistically significant.

${ }^{40}$ Even when adding import penetration and capital accumulation (averaged over 22 sectors) for the 1992-1999 period, there is still a highly statistically and economically significant downward trend in the wages of primary completers. 
by fast-decreasing wages at the bottom. When testing other specifications (i.e. when including public job dummy, firm size, occupation and sector fixed effects) this result remains unaltered.

Second, by considering time-varying returns to schooling in the pooled data I analyse the effects of aggregate shocks by looking at the time trend, and the interaction of time with education over crises years. I find that during both shocks (1995 and 2001) the higher the stock of human capital, the less the impact was on wage levels. It could be argued that education increased the ability of individuals to deal with disequilibria and hence better process information on how to adjust quickly (Schultz 1975, Gould and Weinberg 2001).

Third, the type of shock or policy swing matters as shocks such as the 1995 and 2001 ones do not seem to have particularly affected the increasing trend in the returns. They rather had an equal impact across skill levels, but had non-neutral effects across occupations, clearly affecting more the self-employed and the informal workers. This is consistent with the self-employed and informal workers adjusting via wage reductions while the salaried have gone into unemployment. In contrast, the policy reforms of the early nineties (as identified by regressions by years or year-dummies) seem to had had non-neutral effects across skills.

Fourth, when analyzing in a preliminary way the effects of macroeconomic variables on wages I find that: (i) GDP seems to have a positive but regressive effect on wages, benefiting significantly more college completers with about a 30 percentage points higher increase in wages than their primary completers counterparts; (ii) (lagged) unemployment has a negative effect on wages, more so for the less educated; and (iii) after controlling for all these macroeconomic variables, there is still a statistically and economically significant unexplained downward trend in wages for all workers (of between 2.1 and 4.2 per cent).

These results are consistent with various "stories" on how wages are set at different levels of disaggregation. Skill biased technological change, trade and different abilities to smooth consumption might be part of the explanation as to why a shock in output or any change in the macro time series make the wages of the unskilled fall faster, or the wages of the skilled increase faster. Other papers further analyse these issues, exploiting the available micro-data on capital accumulation and trade, but only focusing in the manufacturing sector.

One implication of this paper is that differences in the returns to different occupations may be part of the explanation as to why in a country with high-unemployment one does not observe workers switching from wage employment to self employment over this period. Furthermore, for studies analyzing policy issues (i.e., whether to subsidize different levels of education); care should be taken as to whether the effects on the returns to education are more permanent than those found here; this awaits further research. 


\section{Definition of variables in regressions}

Dep.var. in wage equations $(\ln \mathbf{W}): \log$ (positive) real hourly earnings at 1998 prices in AR $\$$ on those 14-65 year-old with positive earnings for the available conglomerates for the May waves from 1992 until 2003 (i.e.: La Plata, Cordoba, Parana, C. Rivadavia, Neuquen, Jujuy, R.Gallegos, Salta, S. Luis, S.Rosa, Capital and P.del Conurbano Bonaerense.

Education : Prii=1 if no schooling or incomplete primary school. Between 0 and 6 years of schooling Pric= 1 if completed primary school. 7 years of schooling Seci=1 if did not complete secondary school. B/ 8 and 11 years of schooling Secc=1 if completed secondary school. 12 years of schooling Supi=1 if did not complete university (college) or other form of superior education. B/13 and 16 years of schooling Supc=1 if completed university 17 or more years of schooling $\mathrm{S}=$ years of education completed (computed at average of educational category for period 1992-1994)

Experience/Age : Age: age in years Agesq: age squared Agesq100: agesq/100 Exp: years of potential work experience: (age-S-6)

Employment category (according to main occupation) : Wage employee (wagemp)=1 if employee Self employed (self) $=1$ if self employed Manager (manager) $=1$ if manager Formal=1 if wage employee with some type of benefits (only retirement benefit, combinations with and without retirement benefits and all benefits).

(Log of ) Firm size=(lfirmsize) =linearization of categorical variable "size" with values: 0:0, 1:1, 2:2-5, 3:6-15, 4:16-25, 5:26-50, 6:51-100, 7:101-500, 8:501 or more. Only available for BU and BUA datasets. Continuous from 1995 onwards.

Sector : Categorical variable for 23 sectors. (values available on request). These 23 sectors have been aggregated into 3 sectors: the extractive, the manufacturing and the non-tradable. Public=1 if public job.

Hours worked $(=\mathbf{L})$ : (in reference week) Categorical variable prior to 1995. Continuous from 1995 onwards. Takes values: 1 : 1 to 19,2 : 20 to 29,3 : 30 to 40, 4: 41 to $45,5: 46$ to $61,6: 62$ or more $7: 0$ hours worked. 


\section{$9 \quad$ Figures and Tables}

Figure 1: Average years of education (left)/ Predicted average real wages, by level of education (right): 1992-2003
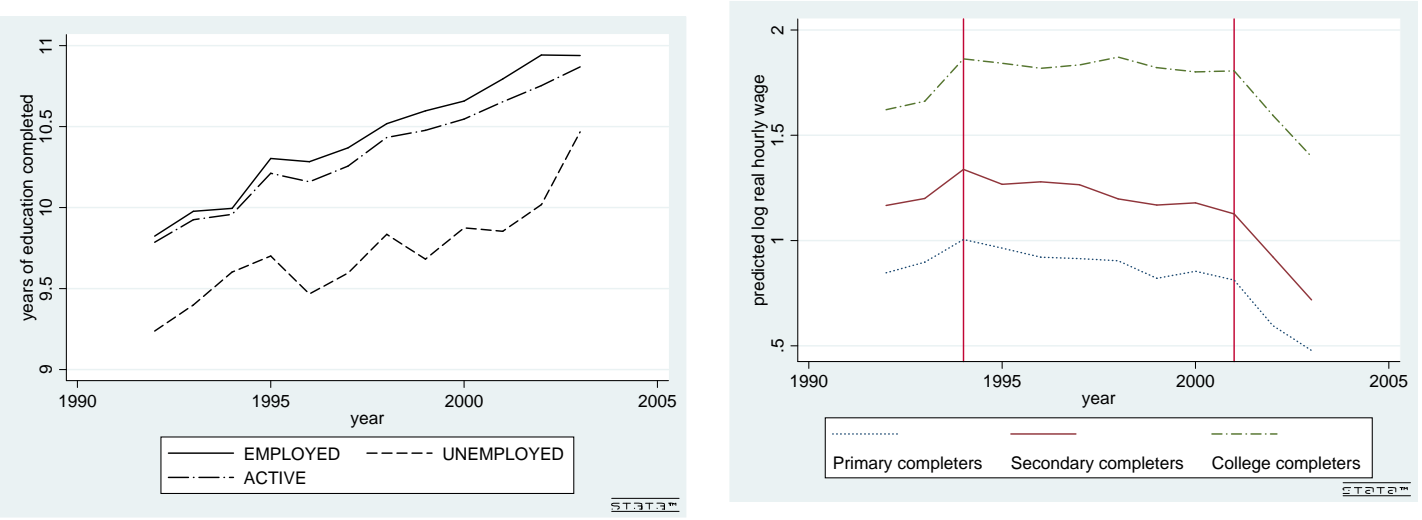

Figure 2: Predicted average real wages, by level of education and occupation (left)/Evolution of wage premium, f(S): 1992, 1998 and 2003 (right)
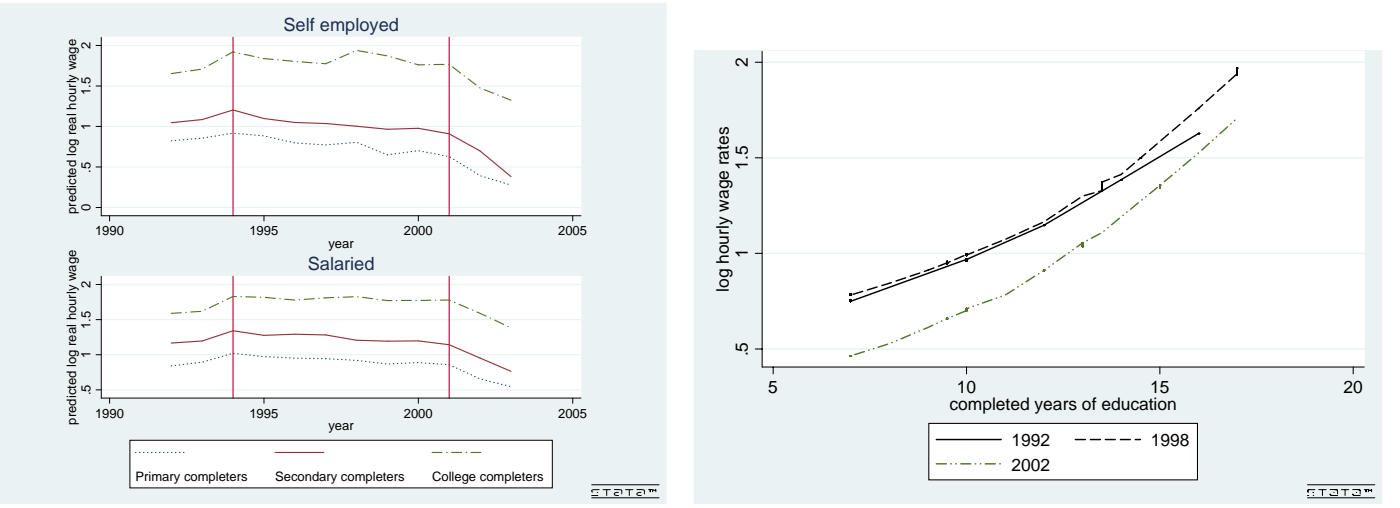

Source: own calculations, EPH, Argentina. May waves. 14-65 year old population. The graph in the right panel of Figure 2 is based on semi-parametric estimation as explained in the text. 


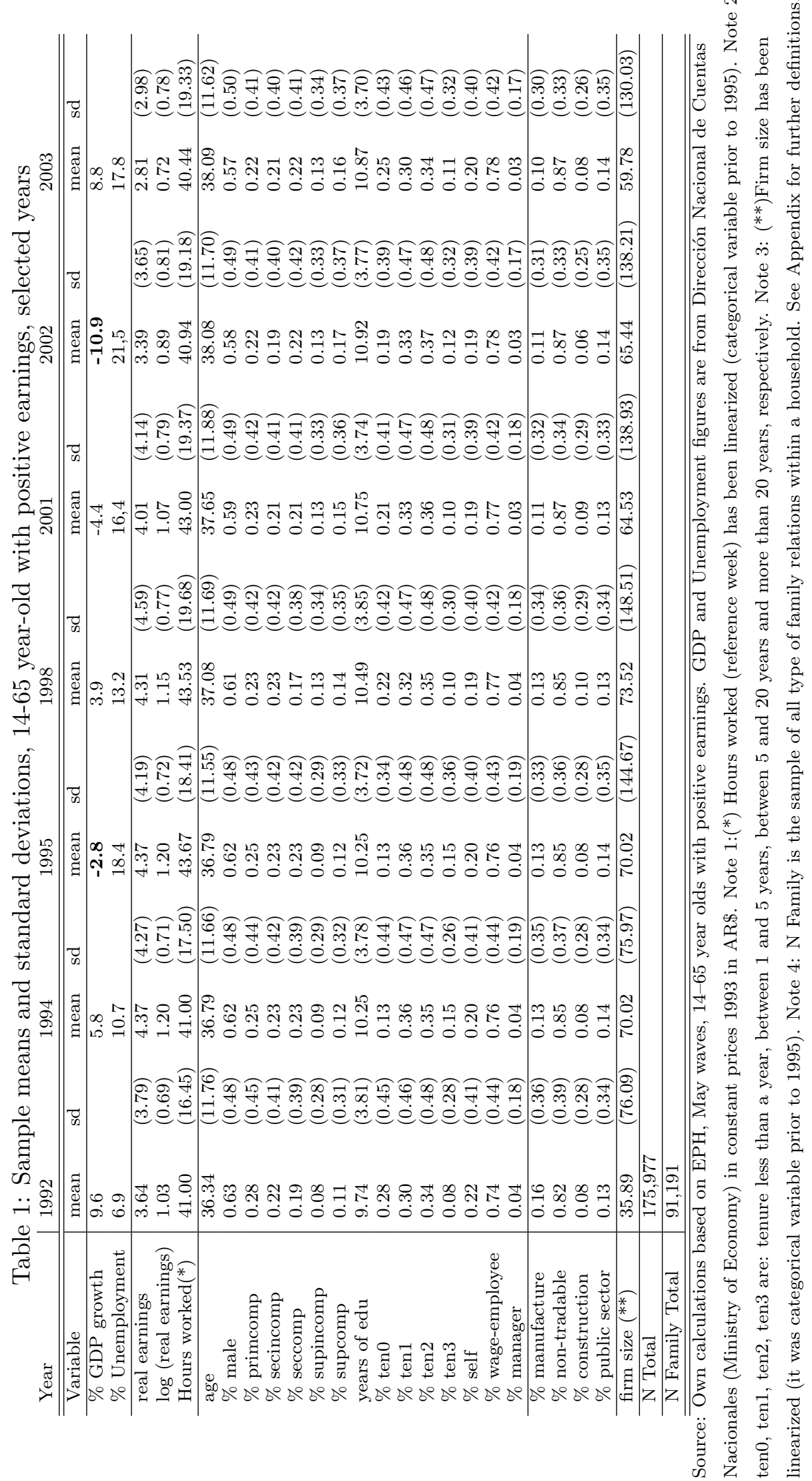


Table 2: Time trend and time-varying returns to schooling: Argentina 1992-2003

\begin{tabular}{|c|c|}
\hline & Pooled data \\
\hline 1993 & $\begin{array}{c}.085 \\
(.020)^{* * *}\end{array}$ \\
\hline 1994 & $\begin{array}{c}.188 \\
(.020)^{* * *}\end{array}$ \\
\hline 1995 & $\begin{array}{c}.138 \\
(.021)^{* * *}\end{array}$ \\
\hline 1996 & $\frac{.114}{(.022)^{* * *}}$ \\
\hline 1997 & $\begin{array}{c}.050 \\
(.022)^{* *}\end{array}$ \\
\hline 1998 & $\begin{array}{c}.047 \\
(.022)^{* *}\end{array}$ \\
\hline 1999 & $\begin{array}{c}.061 \\
(.024)^{* *}\end{array}$ \\
\hline 2000 & $\begin{array}{l}.031 \\
(.024)\end{array}$ \\
\hline 2001 & $\begin{array}{l}-.012 \\
(.025)\end{array}$ \\
\hline 2002 & $\begin{array}{c}-.239 \\
(.027)^{* * *}\end{array}$ \\
\hline 2003 & $\begin{array}{l}-.367 \\
(.030)^{* * *}\end{array}$ \\
\hline Primc & $\begin{array}{c}.209 \\
(.017)^{* * *}\end{array}$ \\
\hline Seci & $\underset{(.018)^{* * *}}{.421}$ \\
\hline Secc & $\begin{array}{c}.639 \\
(.018)^{* * *}\end{array}$ \\
\hline Supi & $\begin{array}{c}.870 \\
(.022)^{* * *}\end{array}$ \\
\hline Supc & $\begin{array}{c}1.110 \\
(.022)^{* * *}\end{array}$ \\
\hline Pric*$^{*} 1993$ & $\begin{array}{l}-.042 \\
(.024)^{*}\end{array}$ \\
\hline Pric*1994 & $\begin{array}{l}-.054 \\
(.024)^{* *}\end{array}$ \\
\hline Pric*1995 & $\begin{array}{l}-.037 \\
(.025)\end{array}$ \\
\hline Pric*1996 & $\begin{array}{c}-.075 \\
(.025)^{* * *}\end{array}$ \\
\hline Pric*1997 & $\begin{array}{l}-.038 \\
(.025)\end{array}$ \\
\hline Pric*1998 & $\begin{array}{l}-.037 \\
(.026)\end{array}$ \\
\hline Pric*1999 & $\begin{array}{c}-.109 \\
(.027)^{* * *}\end{array}$ \\
\hline Pric*2000 & $\begin{array}{l}-.063 \\
(.028)^{* *}\end{array}$ \\
\hline Pric*2001 & $\begin{array}{l}-.076 \\
(.029)^{* * *}\end{array}$ \\
\hline Pric*2002 & $\begin{array}{c}-.061 \\
(.031)^{* *}\end{array}$ \\
\hline Secc*1993 $^{*}$ & $\begin{array}{l}-.063 \\
(.025)^{* *}\end{array}$ \\
\hline Secc*1994 & $\begin{array}{l}-.051 \\
(.025)^{* *}\end{array}$ \\
\hline Secc*1995 & -.078 \\
\hline
\end{tabular}




\begin{tabular}{|c|c|}
\hline & $\frac{(\text { pooled data) }}{(.026)^{* * *}}$ \\
\hline Secc*1996 & $\begin{array}{l}-.044 \\
(.026)^{*}\end{array}$ \\
\hline Secc*1997 & $\begin{array}{l}-.024 \\
(.027)\end{array}$ \\
\hline Secc*1998 & $\begin{array}{c}-.070 \\
(.027)^{* * *}\end{array}$ \\
\hline Secc*1999 & $\begin{array}{c}-.078 \\
(.028)^{* * *}\end{array}$ \\
\hline Secc*2000 & $\begin{array}{l}-.064 \\
(.029)^{* *}\end{array}$ \\
\hline Secc*2001 & $\begin{array}{l}-.069 \\
(.030)^{* *}\end{array}$ \\
\hline Secc*2002 & $\begin{array}{l}-.056 \\
(.031)^{*}\end{array}$ \\
\hline Supi*1993 & $\begin{array}{l}-.049 \\
(.030)\end{array}$ \\
\hline Supi*1994 & $\begin{array}{l}-.024 \\
(.030)\end{array}$ \\
\hline Supi*1995 & $\begin{array}{l}-.027 \\
(.030)\end{array}$ \\
\hline Supi*1996 & $\begin{array}{l}.014 \\
(.030)\end{array}$ \\
\hline Supi*1997 & $\begin{array}{l}.036 \\
(.030)\end{array}$ \\
\hline Supi*1998 & $\begin{array}{l}.029 \\
(.030)\end{array}$ \\
\hline Supc*1993 & $\begin{array}{l}-.024 \\
(.028)\end{array}$ \\
\hline Supc*1994 & $\begin{array}{l}.045 \\
(.028)\end{array}$ \\
\hline Supc*1995 & $\begin{array}{c}.24 \\
(.031)^{* * *}\end{array}$ \\
\hline Supc*1996 & $\frac{.207}{(.031)^{* * *}}$ \\
\hline Supc*1997 & $\begin{array}{c}.250 \\
(.031)^{* * *}\end{array}$ \\
\hline Supc*1998 & $\begin{array}{c}.286 \\
(.031)^{* * *}\end{array}$ \\
\hline Supc*1999 & $\begin{array}{c}.236 \\
(.033)^{* * *}\end{array}$ \\
\hline Supc*2000 & $\begin{array}{c}.219 \\
(.034)^{* * *}\end{array}$ \\
\hline Supc*2001 & $\begin{array}{c}.271 \\
(.034)^{* * *}\end{array}$ \\
\hline Supc*2002 & $\begin{array}{c}.269 \\
(.035)^{* * *}\end{array}$ \\
\hline $\begin{array}{l}\text { Obs. } \\
\mathrm{R}^{2}\end{array}$ & $\begin{array}{c}168,965 \\
0.37\end{array}$ \\
\hline
\end{tabular}

Note 1: Estimates receive one star if they are statistically significant at the $90 \%$ level, two stars at the $95 \%$ significance level and three stars at the $99 \%$ level. Note 2: Controls for urban area fixed effects always present (see Data section for details on the sample). This particular specification includes family FE estimation. Note 3: Controls for age, age squared, a dummy for less than 18 year old and male included. Note 4: All the year interactions with Seci (secondary incomplete) are statistically significant while those with Supi (Superior incomplete) appear statistically insignificant (both not reported for the sake of clarity). 


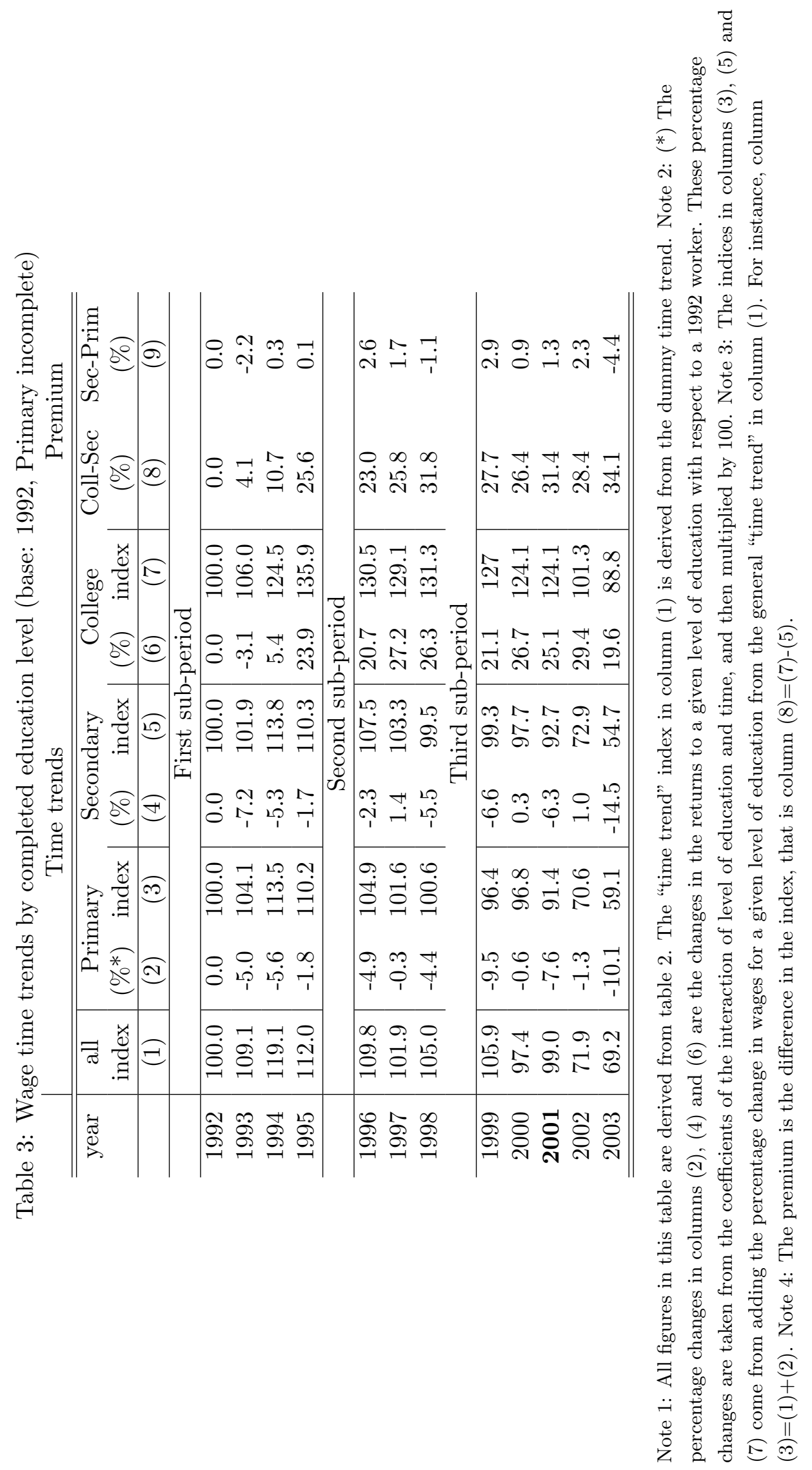




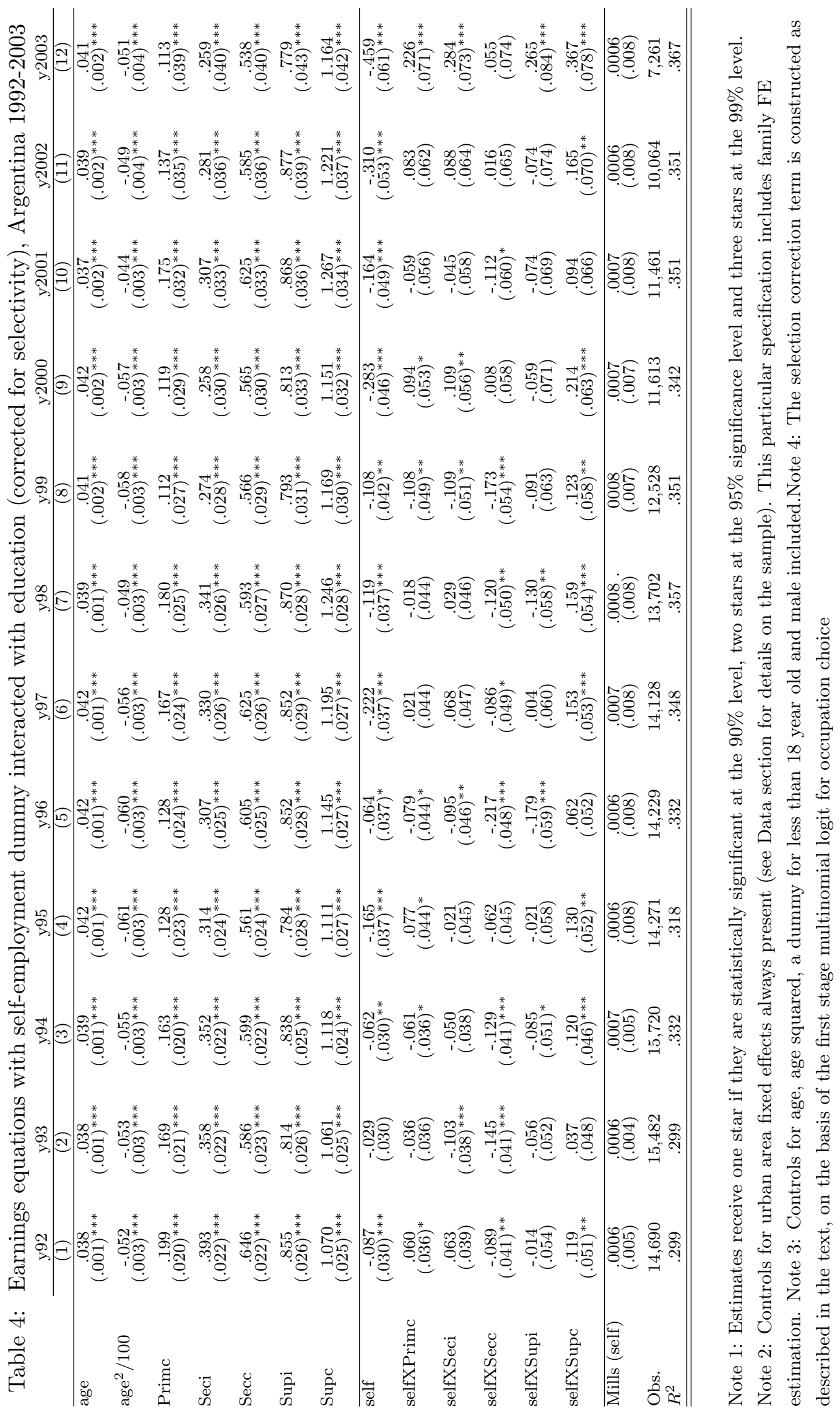




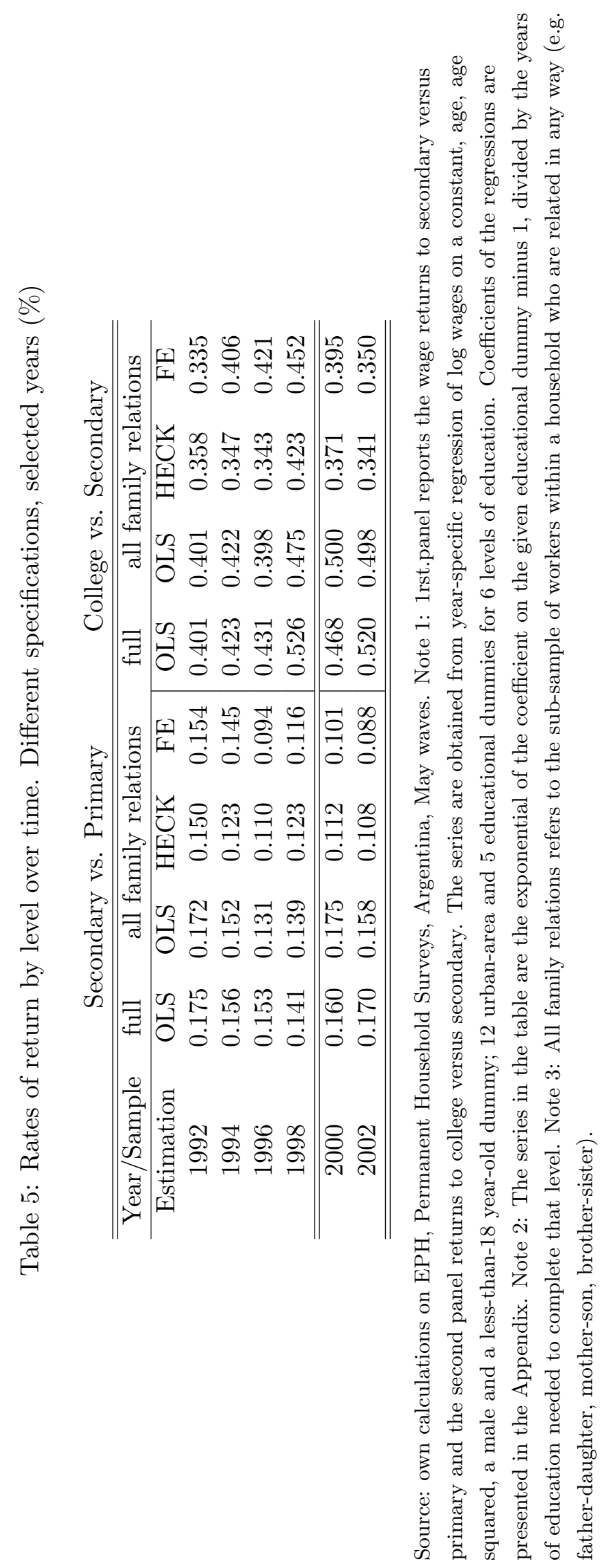




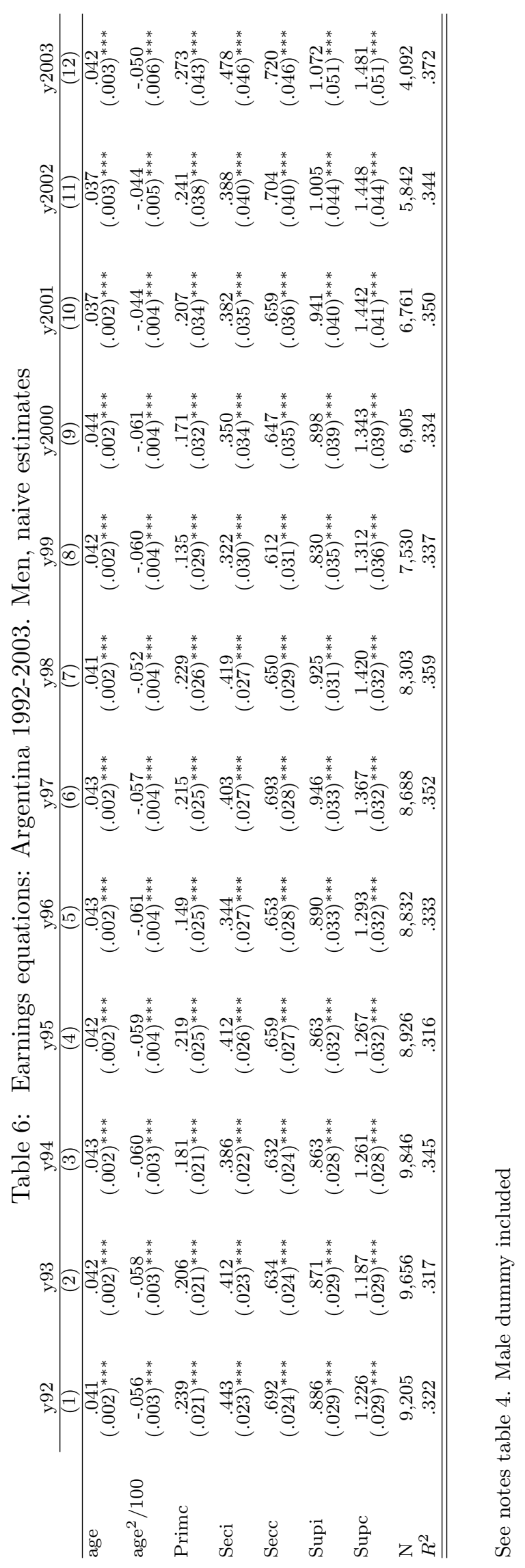




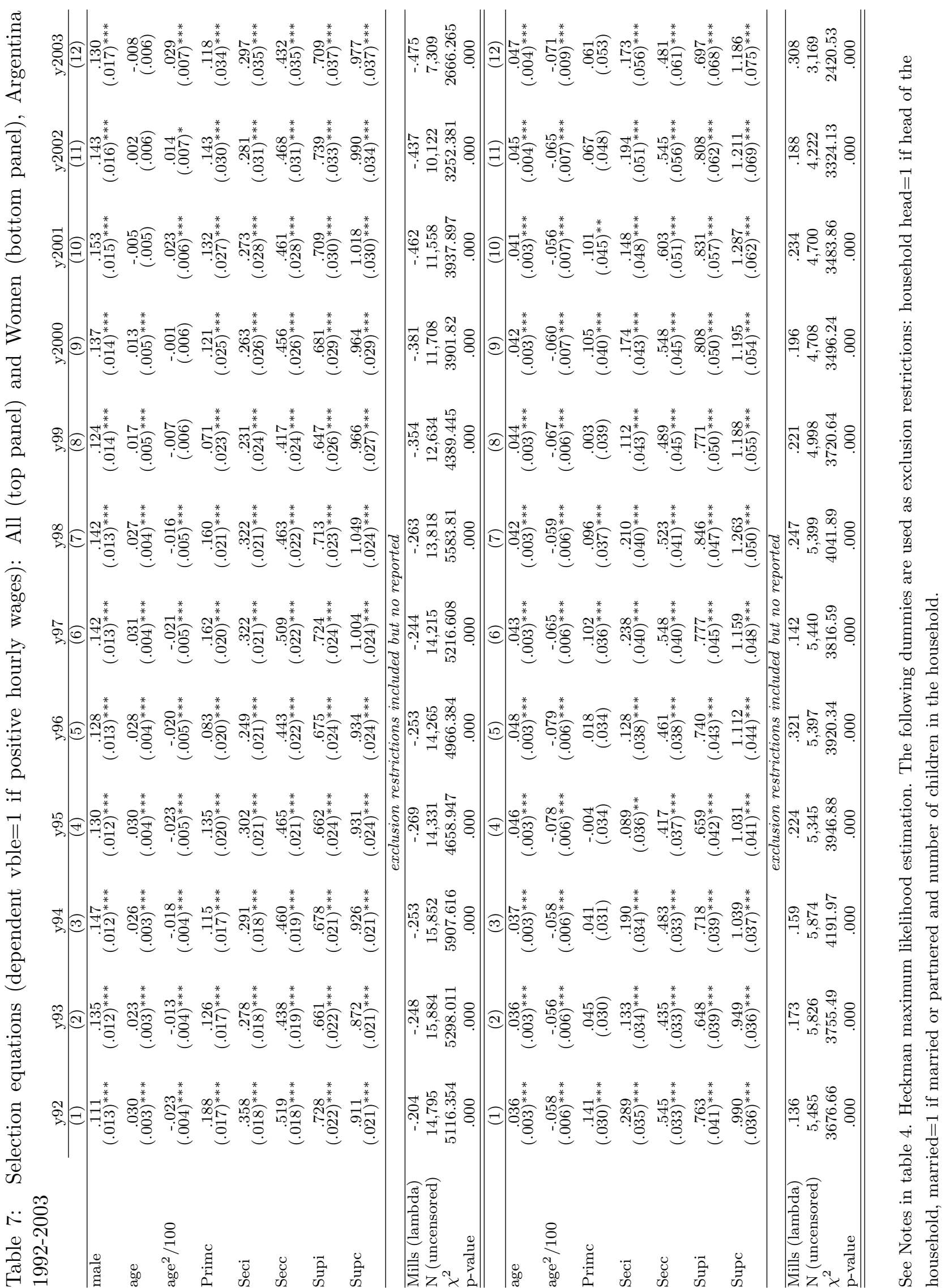




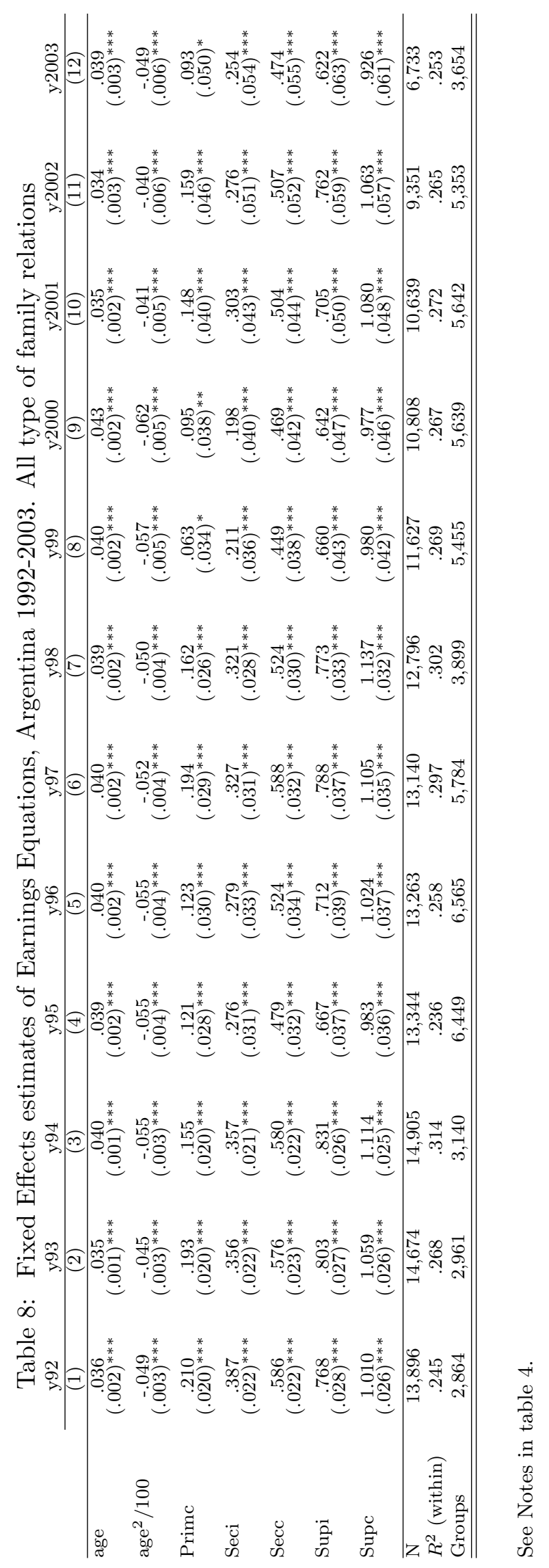




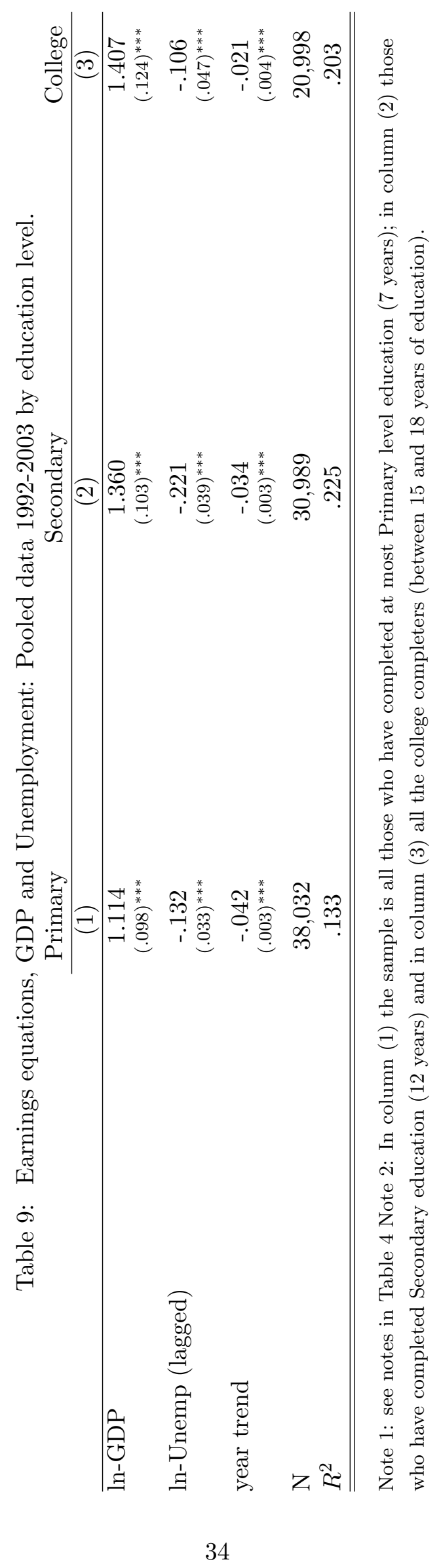




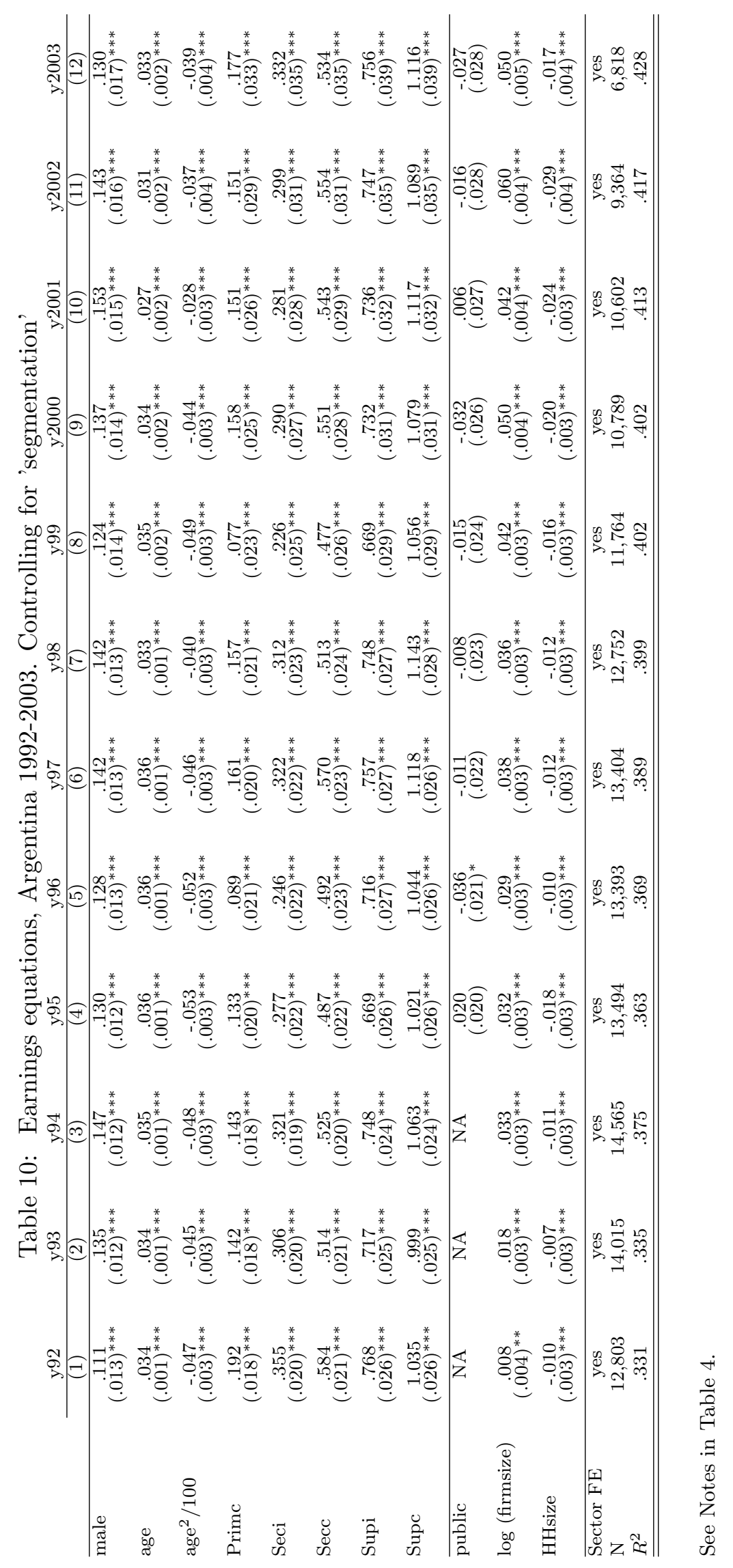


Table 11: Education, by gender and by occupation, \%. Selected years

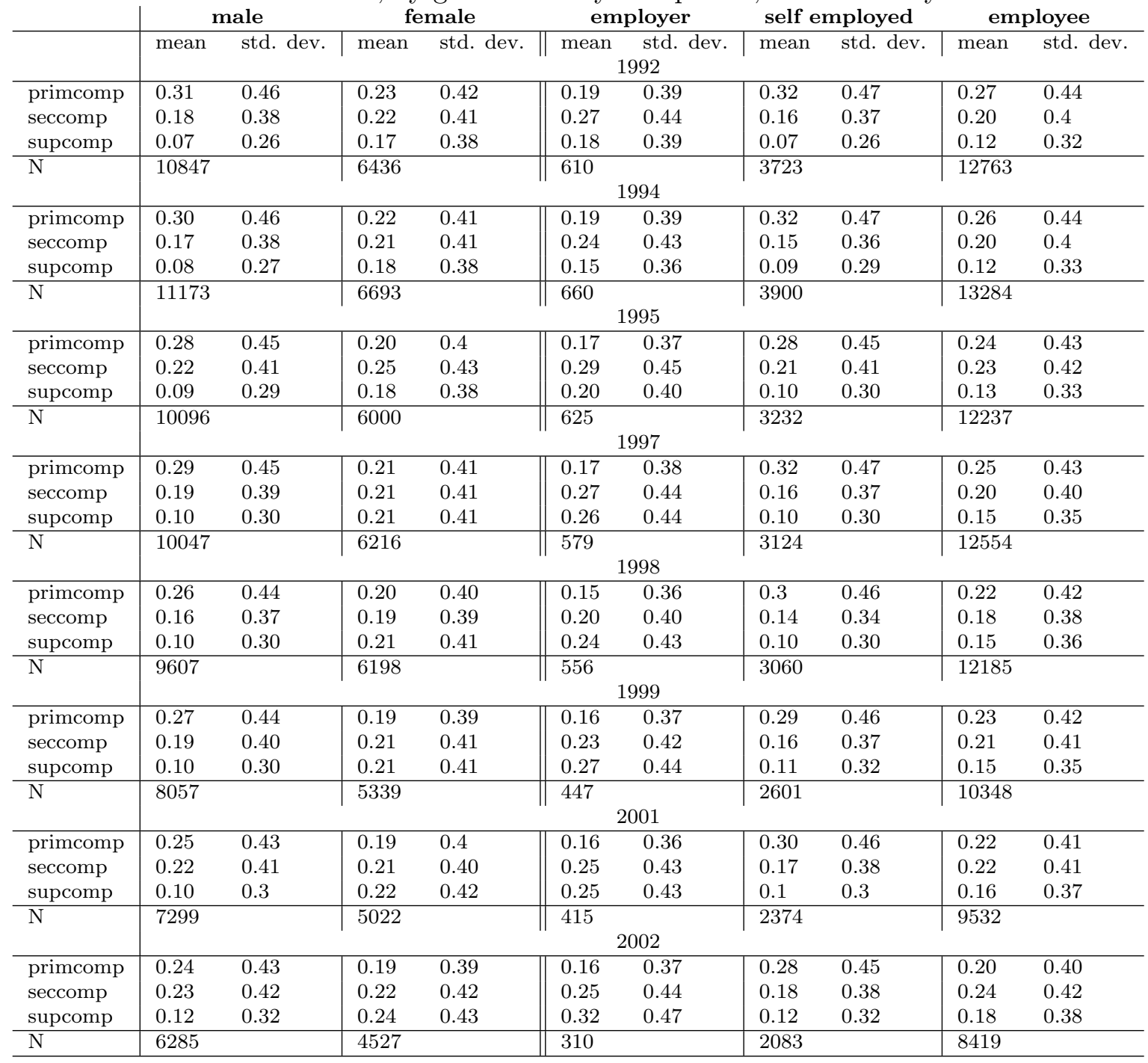

Source: Own calculations based on EPH 


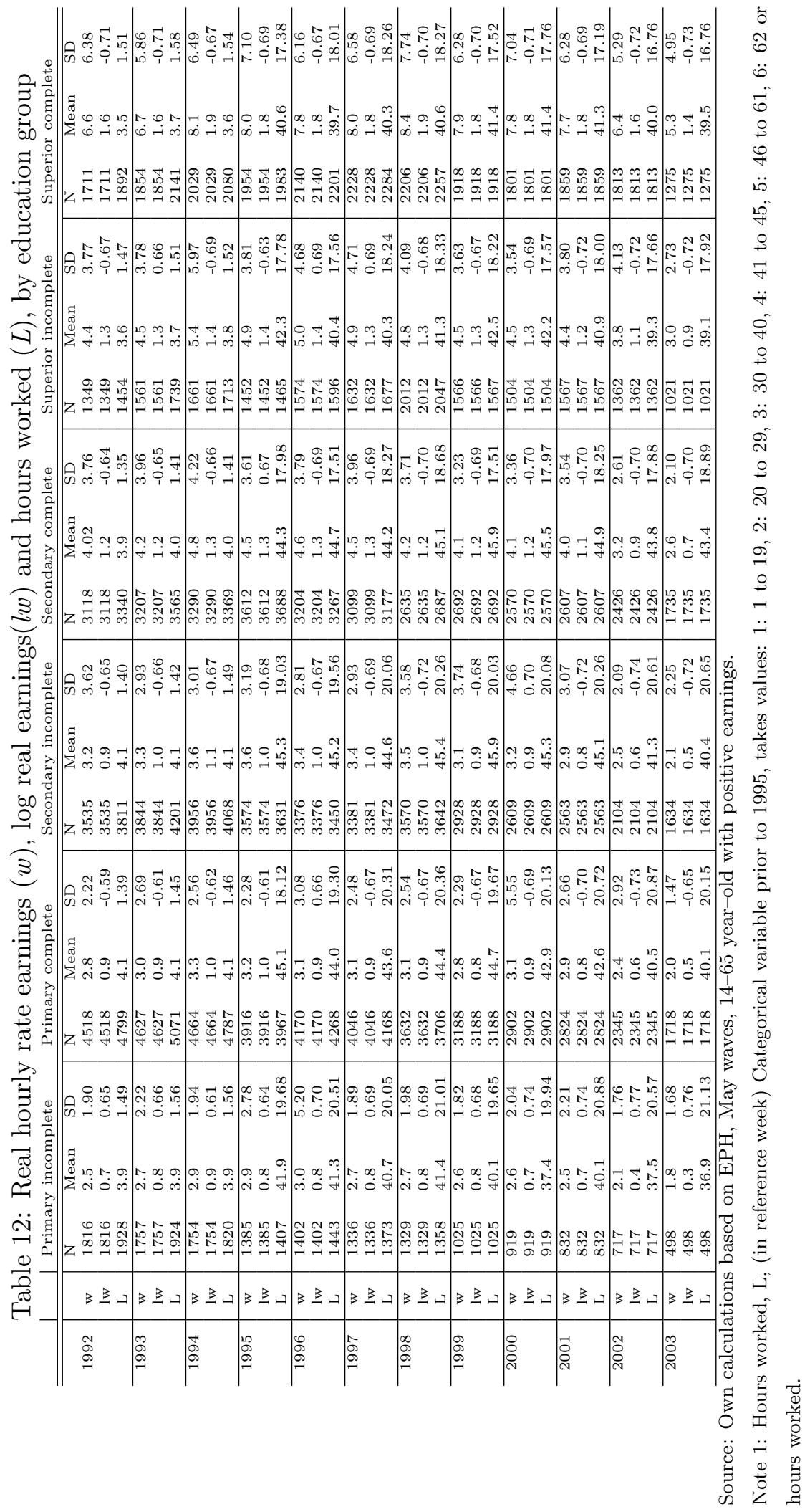


Table 13: Real hourly rate earnings $(w), \log$ real earnings $(l w)$ and hours worked $(L)$, by occupation

\begin{tabular}{|c|c|c|c|c|c|c|c|c|c|c|}
\hline & & \multicolumn{3}{|c|}{ Patron/Owner } & \multicolumn{3}{|c|}{ Self } & \multicolumn{3}{|c|}{ Wage } \\
\hline & & $\mathrm{N}$ & Mean & $\mathrm{SD}$ & $\mathrm{N}$ & Mean & $\mathrm{SD}$ & $\mathrm{N}$ & Mean & $\mathrm{SD}$ \\
\hline \multirow[t]{3}{*}{1992} & $\mathrm{w}$ & 507 & 7.44 & 8.36 & 3409 & 3.47 & 3.87 & 12136 & 3.53 & 3.36 \\
\hline & $\operatorname{lw}$ & 507 & 1.67 & -0.79 & 3409 & 0.92 & -0.78 & 12136 & 1.03 & -0.65 \\
\hline & $\mathrm{L}$ & 610 & 4.82 & 1.21 & 3723 & 4.07 & 1.60 & 12761 & 3.83 & 1.37 \\
\hline \multirow[t]{3}{*}{1993} & $\mathrm{w}$ & 604 & 7.29 & 6.86 & 3760 & 3.61 & 4.34 & 12484 & 3.67 & 3.19 \\
\hline & $\operatorname{lw}$ & 604 & 1.68 & -0.78 & 3760 & 0.95 & -0.79 & 12484 & 1.07 & -0.65 \\
\hline & $\mathrm{L}$ & 749 & 4.85 & 1.16 & 4285 & 4.16 & 1.62 & 13401 & 3.88 & 1.42 \\
\hline \multirow[t]{3}{*}{1994} & $\mathrm{w}$ & 645 & 7.82 & 8.74 & 3794 & 4.19 & 4.77 & 12911 & 4.25 & 3.66 \\
\hline & lw & 645 & 1.72 & -0.79 & 3794 & 1.08 & -0.82 & 12911 & 1.21 & -0.66 \\
\hline & $\mathrm{L}$ & 660 & 4.95 & 1.14 & 3900 & 4.13 & 1.66 & 13277 & 3.89 & 1.43 \\
\hline \multirow[t]{3}{*}{1995} & $\mathrm{w}$ & 651 & 7.66 & 7.35 & 3300 & 4.08 & 4.52 & 12604 & 4.27 & 3.78 \\
\hline & lw & 651 & 1.71 & 0.82 & 3300 & 1.05 & -0.82 & 12604 & 1.21 & -0.68 \\
\hline & $\mathrm{L}$ & 656 & 58.22 & 19.63 & 3349 & 46.28 & 21.65 & 12816 & 42.26 & 16.96 \\
\hline \multirow[t]{3}{*}{1996} & $\mathrm{w}$ & 529 & 9.33 & 9.85 & 3227 & 3.87 & 5.19 & 12111 & 4.18 & 3.52 \\
\hline & lw & 529 & 1.85 & -0.87 & 3227 & 0.98 & -0.85 & 12111 & 1.19 & 0.69 \\
\hline & $\mathrm{L}$ & 533 & 55.81 & 18.75 & 3285 & 46.06 & 22.23 & 12403 & 41.92 & 17.59 \\
\hline \multirow[t]{3}{*}{1997} & $\mathrm{w}$ & 562 & 8.60 & 9.06 & 3033 & 3.79 & 4.27 & 12187 & 4.21 & 3.74 \\
\hline & lw & 562 & 1.79 & -0.84 & 3033 & 0.94 & -0.88 & 12187 & 1.18 & -0.70 \\
\hline & $\mathrm{L}$ & 576 & 56.61 & 19.45 & 3114 & 44.08 & 23.28 & 12520 & 41.93 & 18.07 \\
\hline \multirow[t]{3}{*}{1998} & $\mathrm{~W}$ & 546 & 8.82 & 9.05 & 2998 & 4.11 & 5.97 & 11927 & 4.15 & 3.69 \\
\hline & lw & 546 & 1.81 & -0.85 & 2998 & 0.99 & -0.89 & 11927 & 1.16 & -0.72 \\
\hline & $\mathrm{L}$ & 554 & 55.57 & 19.69 & 3055 & 44.58 & 23.78 & 12176 & 42.73 & 18.30 \\
\hline \multirow[t]{3}{*}{1999} & $\mathrm{w}$ & 447 & 8.09 & 10.64 & 2601 & 3.66 & 4.13 & 10351 & 3.95 & 3.41 \\
\hline & lw & 447 & 1.65 & -0.93 & 2601 & 0.90 & -0.89 & 10351 & 1.12 & -0.70 \\
\hline & $\mathrm{L}$ & 447 & 57.33 & 18.65 & 2601 & 44.36 & 23.74 & 10352 & 43.40 & 17.35 \\
\hline \multirow[t]{3}{*}{2000} & $\mathrm{~W}$ & 475 & 8.13 & 11.22 & 2411 & 3.84 & 7.50 & 9493 & 4.01 & 3.50 \\
\hline & lw & 475 & 1.68 & -0.87 & 2411 & 0.87 & 0.94 & 9493 & 1.13 & -0.71 \\
\hline & $\mathrm{L}$ & 475 & 57.21 & 19.35 & 2411 & 43.05 & 23.95 & 9493 & 42.48 & 17.43 \\
\hline \multirow[t]{3}{*}{2001} & $\mathrm{w}$ & 415 & 7.98 & 8.83 & 2374 & 3.58 & 4.65 & 9534 & 3.94 & 3.56 \\
\hline & lw & 415 & 1.66 & -0.91 & 2374 & 0.82 & -0.95 & 9534 & 1.10 & -0.72 \\
\hline & $\mathrm{L}$ & 415 & 57.25 & 17.91 & 2374 & 42.12 & 24.04 & 9534 & 42.60 & 17.83 \\
\hline \multirow[t]{3}{*}{2002} & $\mathrm{w}$ & 310 & 6.46 & 8.08 & 2083 & 2.91 & 3.92 & 8419 & 3.40 & 3.24 \\
\hline & lw & 310 & 1.43 & -0.92 & 2083 & 0.59 & -0.96 & 8419 & 0.94 & -0.75 \\
\hline & $\mathrm{L}$ & 310 & 55.40 & 17.80 & 2083 & 40.33 & 24.27 & 8419 & 40.56 & 17.53 \\
\hline \multirow[t]{3}{*}{2003} & $\mathrm{w}$ & 222 & 5.54 & 6.47 & 1554 & 2.55 & 3.78 & 6142 & 2.78 & 2.47 \\
\hline & lw & 222 & 1.29 & -0.92 & 1554 & 0.47 & -0.94 & 6142 & 0.76 & -0.71 \\
\hline & $\mathrm{L}$ & 222 & 57.88 & 19.70 & 1554 & 41.32 & 22.94 & 6142 & 39.58 & 17.97 \\
\hline
\end{tabular}

Source: Own calculations based on EPH, May waves, 14-65 year-old with positive earnings.

Note 1: Hours worked, L, (in reference week) Categorical variable prior to 1995, takes values: 1: 1 to 19 , 2: 20 to $29,3: 30$ to $40,4: 41$ to $45,5: 46$ to $61,6: 62$ or more $7: 0$ hours worked. 


\section{References}

Andres, L. (2003): "Private Education versus Public Education: The Effects of the Quality of the Alternative Schooling in Argentina," Discussion paper, University of Chicago, unpublished manuscript.

Angrist, J., And A. Krueger (1991): "Does Compulsory Schooling Attendance Affect Schooling and Earnings," Quarterly Journal of Economics, 106(4), 979-1014.

Ashenfelter, O., and C. Rouse (1998): "Income, Schooling, and Ability: Evidence from a New Sample of Identical Twins," The Quarterly Journal of Economics, 113(1), $253-284$.

Ashenfelter, O., And D. J. Zimmerman (1997): "Estimates Of The Returns To Schooling From Sibling Data: Fathers, Sons, And Brothers," The Review of Economics and Statistics, 79(1), 1-9.

Barro, R. J., AND J. W. Lee (2000): "International Data on Educational Attainment Updates and Implications," NBER Working Papers: 79112000.

Behrman, J., And B. Wolfe (1984): "The Socioeconomic Impact of Schooling in a Developing Country," The Review of Economics and Statistics, 66(2), 296-303.

Berman, E., J. Bound, And S. Machin (1998): "Implications of Skill-Biased Technological Change: International Evidence," Quarterly Journal of Economics, 113(4), $1245-79$.

Blom, A., L. Holm-Nielsen, and D. Verner (2001): "Education, Earnings, and Inequality in Brazil, 1982-98: Implications for Education Policy," World Bank Policy Research Working Paper Series: 26862001.

Bound, J., And G. Johnson (1992): "Changes in the Structure of Wages in the 1980's: An Evaluation of Alternative Explanations," American Economic Review, 82(3), 37192.

Butcher, K. F., and A. Case (1994): "The Effect of Sibling Sex Composition on Women's Education and Earnings," Quarterly Journal of Economics, 109(3), 531-63.

Card, D. (1995a): "Earnings, Schooling and Ability Revisited," in Research in Labor Economics, Vol. 14, ed. by S. P., pp. 23-48. JAI Press, Greenwich, CT.

(1995b): "Using Geographic Variation in College Proximity to Estimate the Return to Schooling," in Aspects of Labour Market Behaviour: Essays in Honour of John Vandercamp, ed. by L. N. Christofides, E. Kenneth Grant, and R. Swidinsky, pp. 201-222. University of Toronto Press, Toronto.

Card, D. (2001): "Estimating the Return to Schooling: Progress on Some Persistent Econometric Problems," Econometrica, 69(5), 1127-60.

Dickens, W., L. F. Katz, and K. Lang (1986): "Are Efficiency Wages Efficient?," NBER Working Papers: 19351986. 
Fafchamps, M., M. Soderbom, and N. Benhassine (2006): "Job sorting in African Labor Markets," CSAE Working Paper series WPS/2006-02.

Fiszbein, A., P. I. Giovagnoli, and I. Aduriz (2003): "The Argentine Crisis and Its Impact on Household Welfare," CEPAL Review, 0(79), 143-58.

Fiszbein, A., H. A. Patrinos, and P. I. Giovagnoli (2005): "Estimating the returns to education in Argentina: 1992-2002," Discussion paper, The World Bank, Policy Research Working Paper Series: 37152005.

Freeman, R. B. (1979): "The Effect of Demographic Factors on Age-Earnings Profiles," Journal of Human Resources, 14(3), 289-318.

Fundación de InVEstigaciones ECOnómicas Latinoamericanas, F. (2002): Productividad, competitividad y empresas. Los engranajes del crecimiento. Buenos Aires.

Galiani, S., And P. SAnguinetti (2003): "The impact of trade liberalization on wage inequality: evidence from Argentina," Journal of Development Economics, 72, 497-513.

Gasparini, L., and P. Acosta (2007): "Capital Accumulation, Trade Liberalization and Rising Wage Inequality: The Case of Argentina," Economic Development and Cultural Change, 55(4), 793-812.

Gasparini, L., M. Marchionni, and W. Sosa Escudero (2001): "Characterization of inequality changes through microeconometric decompositions: The case of Greater Buenos Aires," in The microeconomics of income distribution dynamics: A comparative analysis of selected developing countries., ed. by W. B. IADB. Washington DC.

Gould, E., M. O., And B. Weinberg (2001): "Precautionary Demand for Education, Inequality and Technological Progress," Journal of Economic Growth, 6, 285-315.

Heckman, J. J. (1979): "Sample Selection Bias as a Specification Error," Econometrica, 47(1), 153-61.

INDEC (2000): "Incidencia de la pobreza y de la indigencia en el aglomerado del Gran Buenos Aires," Discussion paper, Ministerio de Economía y Producción, Secretaría de política económica, Instituto Nacional de Estadística y Censos.

Katz, L. F., and K. M. Murphy (1995): "Changes in Relative Wages, 1963-1987: Supply and Demand Factors," in Labor economics. Volume 1 Labor supply and labor demand.Elgar Reference Collection., pp. 384-427. Ashenfelter,Orley C.; Hallock, Kevin F.

Krueger, A. B., and L. H. Summers (1989): "Efficiency Wages and the Wage Structure," Discussion paper, National Bureau of Economic Research, Inc, NBER Working Papers: 19521989.

Kugler, B., and G. Psacharopoulos (1989): "Earnings and Education in Argentina: An Analysis of the 1985 Buenos Aires Household Survey," Economics of Education Review, 8(4), 353-65. 
LACHLER, U. (1999): "Education and Earnings Inequality in Mexico," Discussion paper, World Bank Policy Research Working Paper Series: 19491999.

Layard, R., and S. Nickell (2000): "Unemployment in Britain," in The Economics of Unemployment. Volume 3, ed. by P. Junankar, vol. 122 of International Library of Critical Writings in Economics, pp. 375-423. Elgar Edward, Cheltenham, U.K and Northampton, Mass.

Lazear, E., And R. Moore (1984): "Incentives, productivity, and labor contracts," Quarterly Journal of Economics, 99(2), 275295.

Machin, S. (1996): "Changes in the Relative Demand for Skills," in Acquiring Skills: Market Failures, their Symptoms and Policy Responses, ed. by A. L. Booth, and D. J. Snower, pp. 129-46. Cambridge University Press, Cambridge; New York and Melbourne.

Manacorda, M., C. Sanchez Paramo, and N. Schady (2005): "Changes in Returns to Education in Latin America: the Role of Demand and Supply of Skills," Discussion paper, Centre for Economic Performance, LSE, CEP Discussion Papers, number 0712 .

Margot, D. (2001): "Rendimiento a la educacion en Argentina: un analisis de cohortes," Discussion paper, Documento de trabajo numero 33, Universidad Nacional de la Plata.

McKenzie, D. J. (2004): "Aggregate Shocks and Urban Labor Market Responses: Evidence from Argentina's Financial Crisis," Economic Development and Cultural Change, 52(4), 719-58.

Mincer, J. (1974): "Schooling, Experience and Earnings," in Human Behavior and Social Institutions. Columbia University Press, New York.

Pages, C., M. Busso, A. Micco, E. Lora, U. Panizza, A. Rodriguez, and G. Marquez (2004): Good jobs wanted: Labour Markets in Latin America. InterAmerican Development Bank, Washington DC.

Parandekar, S., S. Espana, and M. P. Savanti (2003): "The impact of the crisis on the Argentine educational process," World Bank Working Paper Series 03/03 Background paper number 7 .

Patrinos, H. A., and C. N. Sakellariou (2005): "Economics volatility and returns to education in Venezuela: 1992-2002," Applied Economics, 38(17), 1991-2005.

Patrinos, H. A., and P. Savanti (2005): "Rising returns to schooling in Argentina, 1992-2002: productivity or credentialism?," Discussion paper, The World Bank, Policy Research Working Paper Series: 37142005.

Perry, G., W. Maloney, O. Arias, P. Fajnzylber, A. Mason, and J. SaAvedra-Chanduvi (2007): Informality: Exit and exclusion. World Bank, Washington DC. 
Perry, G. E., F. H. G. Ferreira, and M. Walton (2004): Inequality in Latin America: breaking with history?, World Bank Latin American and Caribbean studies. Viewpoints. World Bank, Washington, D.C.

Pessino, C. (1993): "From aggregate shocks to labour markets adjustments: shifting of wages profiles under hyperinflation in Argentina," Discussion paper, Documento de Trabajo CEMA numero 95.

(1996): "Returns to Education in Greater Buenos Aires 1986-1993 From Hyperinflation to Stabilization and Beyond," Cuadernos de Economia (Pontifical Catholic University of Chile), 33(99), 205-26, CEMA, Instituto Universitario, Buenos Aires.

Pitt, M., And M. Rosenzweig (1990): "Estimating the Intrahousehold Incidence of Illness: Child Health and Gender Inequality in the Allocation of Time," International Economic Review, 31(4), 969-989.

Psacharopoulos, G. (1994): "Returns to Investment in Education: A Global Update," World Development, 22(9), 1325-43.

Psacharopoulos, G., and H. A. Patrinos (2004): "Human Capital and Rates of Return," in International Handbook on the economics of education, ed. by J. Johnes, Geraint; Johnes. Elgar Edward, Cheltenham, U.K. and Northampton, Mass.

Robbins, Donald, M. G., and A. Menendez (1995): "Wage Dispersion in Argentina, 1976-93: Trade Liberalization amidst Inflation, Stabilization, and Overvaluation," Unpublished manuscript.

Sanchez Paramo, C. (2002): "Unemployment, Skills, and Incentives: An Overview of the Safety Net System in the Slovak Republic," Discussion paper, Unlisted.

Schmitt, J. (1995): "The Changing Structure of Male Earnings in Britain, 1974-1988," in Differences and changes in wage structures, Comparative Labor Markets Series, ed. by L. F. Freeman, Richard B.; Katz. University of Chicago Press, Chicago and London.

Schultz, T. W. (1975): "The Value of the Ability to Deal with Disequilibria," Journal of Economic Literature, 13(3), 827-46.

Söderbom, M., F. Teal, and A. Wambugu (2005): "Unobserved heterogeneity and the relation between earnings and firm size: evidence from two developing countries," Economics Letters, 87(2), 153-159.

Söderbom, M., W. A. Teal F., and G. Kahyarara (2006): "The Dynamics of Returns to Education in Kenyan and Tanzanian Manufacturing," Oxford Bulletin of Economics and Statistics, 68(3), 261.

Welch, F. (2003): "Education in Production," in The Economics of Schooling and School Quality. Volume 1. Labor markets, distribution and growth, ed. by E. A. Hanushek, vol. 159 of International Library of Critical Writings in Economics, pp. 29-53. Elgar Edward, Cheltenham, U.K and Northampton, Mass.

Wood, A. (1995): "How Trade Hurt Unskilled Workers," Journal of Economic Perspectives, 9(3), 57-80. 
(1997): "Openness and Wage Inequality in Developing Countries: The Latin American Challenge to East Asian Conventional Wisdom," World Bank Economic Review, 11(1), 33-57.

YATchew, A. (1997): "An elementary estimator of the partial linear model," Economic letters, 57(2), 135-43. 